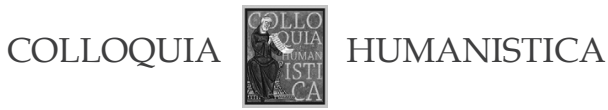

\author{
Eliezer Papo \\ Hebrew Literature Department \\ Ben-Gurion University of the Negev \\ Beer Sheva \\ https://orcid.org/0000-0003-3333-9484 \\ papoe@bgu.ac.il
}

\title{
Ham Ribi Avram Finci's Ladino Translation of Selected Texts from the Zohar as a Rare Glimpse into the Methodology of Traditional Bosnian Sephardic Yeshivot (Adult Learning Clubs) and Its Relation to the Local Sufi Islamic Tradition of Ders ${ }^{1}$
}

\begin{abstract}
In traditional Sephardic culture, theoretical Kabbalah was an exclusive patrimony of the rabbinic elite. From the 17th century onward, many Sephardic laymen found even the Hebrew liturgical, and especially speculative, texts to be impenetrable and incomprehensible. Consequently, the rabbinic elite began to translate liturgical texts and halakhic works into popular Judeo-Spanish. However, the Zohar was usually not included in these projects of cultural intermediation. Consequently, a Judeo-Spanish translation of the integral text of the Zohar, or even of one of its volumes, does not exist to this day. At the same time, different Sephardic rabbis translated selected excerpts from the Zohar into the vernacular. This paper analyses one such anthology, Avram ben Moshe Finci's Leket a-Zoar, published in 5619 (1858/9) in Belgrade. The anthology contains 246 excerpts from the Zohar,

1 This research was supported by THE ISRAEL SCIENCE FOUNDATION (grant No. 592/16).

This is an Open Access article distributed under the terms of the Creative Commons Attribution 3.0 PL License (creativecommons.org/licenses/by/3.0/pl/), which permits redistribution, commercial and non-commercial, provided that the article is properly cited. (c) The Author(s), 2020.

Publisher: Institute of Slavic Studies, Polish Academy of Sciences

Editor-in-chief: Jolanta Sujecka

Conception and academic editing of this issue: Aleksandra Twardowska, Katarzyna Taczyńska
\end{abstract}


121 of which conclude with Finci's own reflections and a resumé of the moral of the story. Many of Finci's discourses are masterpieces of the traditional JudeoSpanish oral genre of darush. Finci was not interested in explaining theoretical kabbalistic terms and concepts. Rather, he reads the Zohar as if it were a work of Mussar. The traditional learning of Bosnian Sephardim seems to resemble, in both methodology and content, the learning traditions of their Muslim neighbours, showing once again that settled communities such as the Ottoman Sephardim cannot be researched only in the context of their affinity to the Jewish world. It is impossible to understand the way the Ottoman Sephardim developed Jewish concepts, practices and institutes without acknowledging the common Ottoman culture they shared with their Muslim and Christian neighbours.

Key words: Sephardic studies, Sephardic culture, Ladino literature, Ottoman Jews, Bosnian Jewry, Rabbinic literature in Judeo-Spanish, Sephardic Sermon, Judaism \& Sufism, Balkan Culture, Balkan Jews.

\section{Introduction}

Tn traditional Sephardic culture, theoretical Kabbalah was an exclusive patrimony of the rabbinic elite. Since the bulk of the classic kabbalistic literature is written in Aramaic, but in the familiar Hebrew square script, the overwhelming majority of Sephardic laymen were capable of reproducing excerpts from these texts, usually as part of pseudo-liturgical (or even prophylactic and magical) reading, mostly without understanding their content even on the most basic level, let alone the esoteric one. In most cases, the texts circulated amongst male Sephardic "commoners" for ceremonial readings of the Zohar at traditional meldado ${ }^{2}$ or lel shemurim ${ }^{3}$ ceremonies were taken from Idrah Rabbah, Idrah Zutah or Tiqune haZohar. The participants of these rituals were not expected to be acquainted with the actual volumes of the Zohar, let alone to have them in their possession. Instead, many different authors prepared and published special booklets for these occasions, containing all the passages usually recited during a specific ritual. Every synagogue owned a substantial number

\footnotetext{
2 A commemoration service held at a private home or synagogue, also called anyo ("year") or petira ("demise").

3 A vigil before the circumcision of a male child, on the eighth day of his life. Due to the widespread belief that the night before the circumcision was the "last chance" for Lilith to hurt the child, who from the next day on would be protected by the sign of the covenant with the Divine made in his flesh, traditional Sephardim used to organise a prophylactic magical watch, spending the entire night sitting around the new-born and reading sacred texts, including from the Zohar.
} 
of copies of these booklets, and at a time of need they would be brought to private homes. Sometimes many people read the same text in its entirety, especially if the people involved in the ceremony were hakhamim (erudite persons) or talmide hakhamim (semi-erudite persons) used to long reading sessions. However, when the majority of the participants were 'ame ha-ares (commoners), different portions of a single textual unit would be distributed amongst them and the text would be read only once, with everyone reading their own portions in unison. In order to make the distribution easier, the text of Idrah Rabbah or Idrah Zutah would often be divided into a few dozen volumes of two or three pages, each bound separately. If one of the readers present was a hakham, he might reflect on some of the concepts, ideas or stories mentioned in the Aramaic text. Otherwise, the sole purpose of the reading was for its merit to help the deceased in the better world. The same was true of the Aramaic passages from the Zohar read at Lel shemurim.

This sentiment is well presented in the approbation of Ham Ribi Hayyim Matatya Benaroya, a "pure Sephardi" from Filibe (Plovdiv) in Bulgaria, to Finci's Leket a-Zoar:"

$\ldots$ and we are in possession of a tradition that even its mechanical reading is advantageous, and how much more so when it is translated [....] דמסורת בידנו להיות לו סגולה אפילו בקורא להגיה, וכ"ש היות הדבר מתורגם בלשון לעז. into the vernacular. ${ }^{5}$

From the 17th century onward, many Sephardic laymen found even the Hebrew liturgical, and especially speculative, texts to be impenetrable and incomprehensible. Consequently, the rabbinic elite began to translate liturgical texts (including weekday, Sabbath and holiday prayer books, the Pentateuch, the weekly readings from the prophets, the Mishnaic treatise Ethics of the Fathers or the Passover Haggadah) and halakhic works (such as Shulhan 'Arukh) into popular Judeo-Spanish. Many original works were also produced in Ladino (Lehmann, 2005), the most well-known of them being the Midrashic anthology Me'am Lo'ez. In a rare example of a 166-year-long literary dialogue between the learned elite and the common masses, this voluminous encyclopaedia of Jewish knowledge was produced in the vernacular by ten leading Ottoman Sephardic sages. Its name, Me'am Lo' $e z$, is taken from Psalm 114: "when Israel went out of Egypt, the house of Jacob from a people of strange language". This title succinctly

\footnotetext{
4 When Hebrew words appear in the title of a Ladino work, they are regarded and transliterated as Ladino Hebraisms.

5 Translations are mine.
} 
summarises the purpose of the work as perceived by its elite authors: "Judah was His sanctuary, and Israel His dominion". To put it another way, the main aim of the book was to take the Sephardim out of Egypt (as a metaphor for barbarism and ignorance of the Divine Law) and out of their "strange language" (i.e. Ladino, which was viewed by the rabbinic elite of the time as non-Jewish, secular and mundane, in opposition to the Jewish, sacred and transcendental Hebrew), and to equip them with minimal knowledge of the Hebrew sacred text and maximal knowledge of its content and the ensuing concepts and practices. Only by translating Judaism into the vernacular could the vernacular be beaten and could the Djudios ("people of Judah", i.e. Jews) be reconsecrated ("Judah was His sanctuary") and re-subjugated to their Divine king ("and Israel His dominion").

Written in the form of a commentary on 11 biblical books (the five books of the Pentateuch, together with Joshua, Isaiah, Esther, Ruth, Ecclesiastes, and Song of Songs), Me'am Lo'ez anthologised traditional Sephardic knowledge (biblical commentary, Halakhah, rabbinical stories and folklore), creating a sort of "Sephardic Talmud". ${ }^{6}$

\section{Ladino Translations of Selected Texts from the Zohar}

However, while various volumes of Me'am Lo'ez quote passages from the Zohar (mostly stories or explanations of biblical verses), a translation of the integral text of the Zohar, or at least of one of its volumes, into the vernacular was not part of the Sephardic canon. To the best of my knowledge, there is a single manuscript of a Ladino translation of the Zohar's commentary on an entire weekly Torah portion. This was produced (or, at least, copied) at a relatively early date by Moshe Suri 'Asa'el, in the 17th century, and is presently preserved at Harvard University.

Following the tradition of translating liturgical and pseudo-liturgical texts into the vernacular, those excerpts from the Zohar that acquired this status in Sephardic tradition were of course translated integrally. Thus, there are two known late (19th-century) manuscripts of Idrah Rabbah, one from

\footnotetext{
6 Not unexpectedly, the first researchers to address the anthology in a monographic manner were Moshe David Gaon and Michael Molho, the pioneers of Sephardic studies (see Gaon, 1932; Molho, 1945). Luis Landau's unpublished PhD thesis (Landau, 1980) opened the question of the content and form of the initial part of the midrash, produced by R. Jacob Khuli (i.e. Me'am Lo'ez on Genesis and the first two-thirds of Exodus). A series of subsequent studies on these two volumes has advanced our knowledge regarding the anthology and its initiator.
} 
the circle of Salonica's Ma'aminim ${ }^{7}$ and the other from Gibraltar, ${ }^{8}$ as well as two late (19th- and 20th-century) manuscripts of Idrah Zutah, one from Gibraltar, ${ }^{9}$ the other from Izmir. ${ }^{10}$ In 1876 a printed Ladino translation of Idrah Zutah appeared in Izmir under the title Petirat Ribi Shimon ben Yohay (The Demise of R. Shim' on ben Yohay).

The provenance of the texts from the above-mentioned Salonica Ma'aminim circle is readily apparent from their peculiar Soletreo orthography, such as the spelling tikun with tet instead of tav, a practice found solely among partially Islamised Sabbatians. A translation of selected tiqunim from Tiqune ha-Zohar is also extant, ${ }^{11}$ as is a very late (1938) manuscript of the Ladino translation of the Patah Eliyahu passage from the Zohar. ${ }^{12}$

The first printed edition of selected excerpts from the Zohar, however, was published in the year 5600 (1839/40) in Salonica by Eliyau Djahun, under the title Sefer mezake et a-rabim: Livro Ladino i son palavras de Zoar a-Kadosh. ${ }^{13}$ Nevertheless, Avram ben Moshe Finci's Leket a-Zoar, printed in 5619 (1858/9) in Belgrade, appears to have been better received by the Sephardic reading public, as can be deduced from its two subsequent editions: Salonica 5627 (1866/7) and Izmir 5637 (1876/7). The present article will concentrate on this particular anthology, which contains selected texts from the first two volumes of the Zohar: Genesis and Exodus. Its author, Ham Ribi Avram, was a scion of the famous Finci Bosnian ${ }^{14}$ rabbinical dynasty.

\footnotetext{
7 The National Library of Israel, Jerusalem, Israel, Ms. Heb. 917=8; approximately 5597 $(=1836 / 37)$. The name of the scribe: Yaakov Ha-Levi.

8 Meir Benyahu, Ms. NA 396, microfilm F 72003, National Library of Israel, Jerusalem.

9 Meir Benayahu, Ms. NA 397, microfilm F 72004, National Library of Israel, Jerusalem.

10 Petirat Ribi Shimon ben Yohay, Ben-Zvi Institute 3566, Izmir 5628 (1967/1968).

11 Ms. Heb. 919=8, National Library of Israel, Jerusalem (circa 5597 [1836/1837]). Scribe's name: Ya’akov ha-Lewi.

12 Michael Krupp, Ms. 1449, microfilm F 71330, National Library of Israel, Jerusalem. Scribe's name: Yehuda Hizqiya Kareo. Concerning the method of transliteration of the title, see note 4 above.

13 Concerning the method of transliteration of the title, see note 4 above.

${ }^{14}$ For a study of the history of the Jews of Sarajevo from the community's founding until the Austro-Hungarian conquest, see the pioneering work by Moritz Levy (1996, reedition) as well as the chapter on Bosnia by Yakir Eventov (1971). Levy's book was translated into Judeo-Spanish and published in 1932 under the title Los Sefaradim de Bosna por Dr. Gran Rabino de Sarayevo by the Salonica newspaper La Aksion. It was also translated into Serbo-Croatian (Levi, 1969). For a more recent history of this community, see Maestro (1991) and Pinto (1987).
} 


\section{The Fincis: ${ }^{15}$ \\ A Fine Example \\ of an Ottoman Sephardic Rabbinic Dynasty}

Avram ben Moshe Finci was a grandson of Ham Ribi Josef Finci, as mentioned by the author himself in paragraph 199 (misnumbered in the anthology as 201): ${ }^{16}$

Yo me akodro kuando era kriatura, mala-mata ${ }^{17}$ el anyo de [5]573, rosh hodesh Tamuz, se fue mi senyor papu, $\mathrm{Ha}[\mathrm{ham}]$ Josef Finci a[lav] a[shalom] leir a-kodesh Yerushalayim, ti[bane] ve[timale] vi[meera] ve[yamenu]...
I remember when I was a child, more or less in the year [5]573, by the beginning of the month of Tamuz, my grandfather, $\mathrm{Ha}[\mathrm{ham}]$ Josef Finci, pea[ce be upon] hi[m], to the Ho[ly] Ci[ty] of Jerusalem, [may it be] bu[ilt] and fi[led with people] fa[st] and [in our own days]...

He was also a younger brother of Ham Ribi Josef Finci, also known as Waylaqet Yossef (after the title of his alphabetic Hebrew compilation of rabbinic knowledge), who was the firstborn son of the family and consequently, according to Sephardic tradition, was named after his paternal grandfather, a fact mentioned in paragraph 15:

15 On another famous Bosnian rabbinic dynasty, the Pardos, see E. Papo (2006).

${ }_{16}$ Finci's work is written in Ottoman rabbinical Judeo-Spanish, with some dialectal peculiarities typical of colloquial Bosnian Judeo-Spanish. In an introductory article to Samuel Romano's dictionary of colloquial Bosnian Judeo-Spanish, David Bunis summarised the history of research on this dialect and the literature written in it (Romano, 1995). Since the publication of this summary, research on Bosnian Judeo-Spanish has been advanced by several studies. See, for example, Bunis (2001); Nezirović (1988, 2002); E. Papo (2006-2007, 2007, 2008, 2013); I. Papo (1995); Quintana (1997).

17 From the two Hebrew words מעלה (above) מטה (below), the Sephardim coined the term מעלה-מטה which serves in Judeo-Spanish as the Hebrew equivalent of the Spanish mas o menos (more or less). This term is not attested amongst non-Sephardic Hebrew speakers. For the Hebrew component in written and spoken Judeo-Spanish in modern times, see Bunis (1993). For the Hebrew component in spoken Judeo-Spanish in Bosnia and Herzegovina, see I. Papo (1981). David Benveniste's dictionary focuses mainly on Hebrew words that were absorbed into the spoken language, especially in the Salonica and Jerusalem dialects. All the Hebraisms (including biblical verses quoted in Hebrew) and Ottoman Turkisms (of Turkish, Arabic or Persian origin) in the Judeo-Spanish translation of excerpts from the Zohar are presented in italics. However, since this article does not focus on philological issues and is not aimed primarily at scholars from the field of Sephardic studies, I have decided to spare the re- 
Sigun vimos kon muestros ojos en la Bosna, yi [shmor] a[lea] E[loim], ke avia un gevir, ke se yamava $\mathrm{Ha}[\mathrm{ham}] \mathrm{Asher}$ ben Shelomo, $n$ [uhato] e[den], ke non tenia ijos, i izo yeshiva, i asento a mi senyor ermano, ahi verosh, baal Vaylaket Yosef, z[eher] ș[adik] ve[kadosh] li[vraha], por rosh yeshiva, i aparto de su mondea tantos fyori[nes] i avrio butika en desparte, i de akea ganansia se mantenia el haham de la yeshiva, i el She [m] Yit[barah] le pago a ojos de todo el mundo, ke despues ke ya iva kazado kon segunda mujer i non tenia ijos, salvo ijas, i kuando ya le nasia algun ijo, no lo alkansava de destetar, ke se le morian chikos, i kuando izo la yeshiva ke se nombra ad ayom, "measher shemena lahmo," engrandesio...
As we saw with our own eyes in Bosnia, [may] G[od] p[rotect] i[t], where there was a rich man by the name of $\mathrm{Ha}[\mathrm{ham}]$ Asher ben Shelomo, [may he] r[est in] P[aradise], who did not have any sons, and he formed a rabbinic academy, and he brought my master and brother, my brother and head, the author o the book Waylaqet Yossef, [may the] me[mory of the] ri[ghteous] and [a saint] be a b[lessing], to serve as the Head of the Academy, and he set apart from his money [an endowment] of so and so [golden] flori[ns], endowing also a store from which the Head of the Academy was sustained, and God, may $\mathrm{He}$ be blessed, paid him in the eyes of all the people, because after being married to the second wife with whom he had no sons, only daughters, and even when he would have a son, he wouldn't wean them, as they used to die on him while still very young, and once he established the academy, which is renowned until today, two sons were born to him and he brought them up...

ader dozens of footnotes on the etymologies of the non-Iberian strata of (Bosnian) rabbinical Judeo-Spanish. However, each such word is not only indicated by the italic typeface, but also fully accounted for in the accompanying English translation, so that interested readers will receive this etymological information.

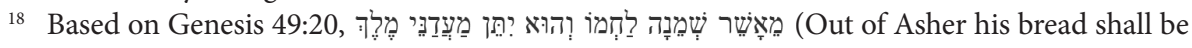
fat, and he shall yield royal dainties). 


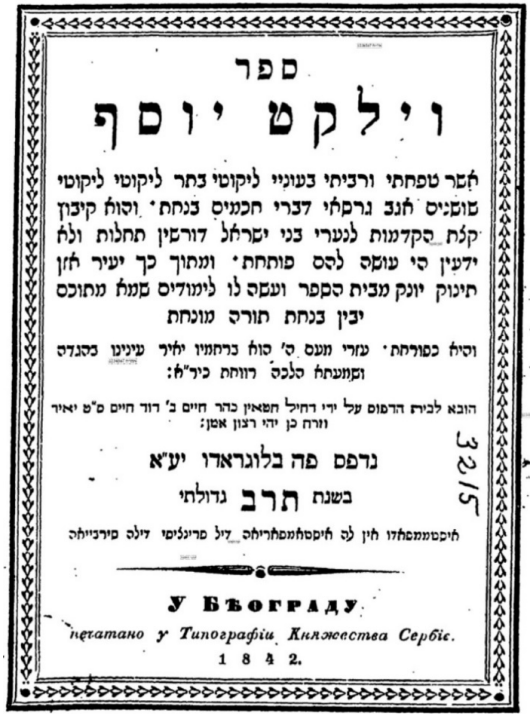

Fig. 1. The front page of the book Waylaqet Yossef

In 1837, when Ham Ribi Reuven Baruh left Belgrade, Ham Ribi Josef Finci was appointed chief rabbi of Belgrade, a position he filled until his death in 1850 (Lebl, 1990, p. 37, 2001, p. 81). Josef Finci's son, Ham Ribi Jeuda Leon Finci, the renowned author of Tiqun Hasot, spent some time with his father in Belgrade, but was later called back to Sarajevo (Lebl, 1990, pp. 37-38). In 1868, when Bosnian Hakham-bashi (Chief Rabbi) Avram Levi left for the Land of Israel, no Bosnian rabbi was willing to accept the position of chief rabbi of the community. Consequently, a bet din (rabbinical court) of three served as a collective "chief rabbi" until 1884. Ham Ribi Jeuda Leon ben Josef Finci was one of the three judges (Kamhi, 1966) who sat on this court, the others being Ham Ribi Bension Pinto and Ham Ribi Eliezer ben Santo (Shemtov) Papo. ${ }^{19}$ According to his descendant Isak

\footnotetext{
19 The most prolific Judeo-Spanish rabbinic author from Sarajevo, Papo was also the spiritus movens behind the establishment of the Hebrew press in Sarajevo. According to the instructions of the Tanzimat from 1865, district rulers throughout the Ottoman Empire were obliged to establish a printing press in the capital of their district, to print a newspaper in the local language and in the letters customarily used in it. The Bosnia wazir at that time, Topal Šerif Osman Pasha, applied the law, and in April 1866 the first printing press was opened in Sarajevo. Papo turned to the wazir in the name of the Jews of Sarajevo with a request that the new printing house obtain Hebrew letters so that the Jews, too, could enjoy it, as can be learned from a critical article published in instalments in El Korreo de Viena, issues 8, 9, and 10 (1872). His alphabetical collection of Sabbath laws, Meshek Beti, was the first Jewish book printed in Sarajevo (1871/1872). Katja Šmid recently published a scientific edition of the book with a thorough introduction and valuable critical apparatus (Šmid, 2012). For additional information about this author, see Bunis (1984) and Alexander \& Papo (2006-2007).
} 
Kabiljo, Ham Ribi Jeuda Finci also served as a member of the City Council of Sarajevo and was known to all the inhabitants of Sarajevo as Hodža Finci (Lebl, 1990, p. 37).

While there seems to be no preserved photo of Avram Finci, the translator of the Zohar, his nephew's picture was preserved thanks to Ribi Moritz Levy's monograph (Levy, 1996):

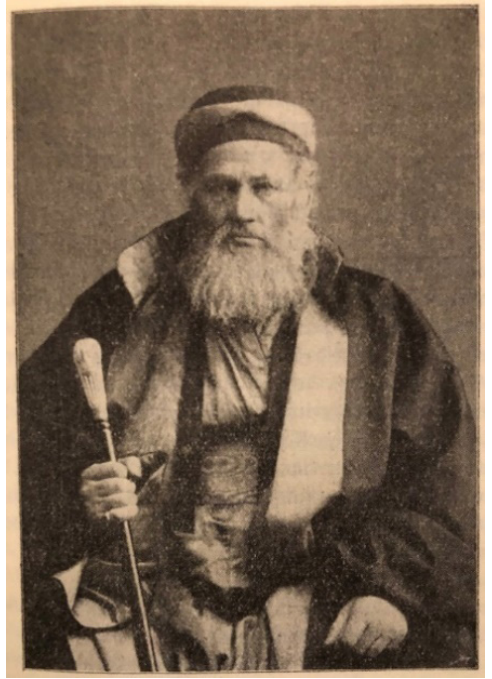

Fig. 2. Ḥam Ribbi Jeuda Leon Finci

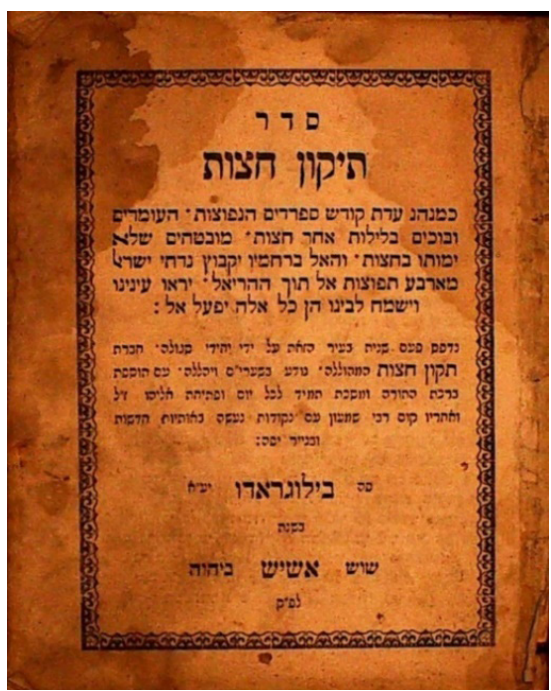

Fig. 3. The front page of his book Tiqun Hașot

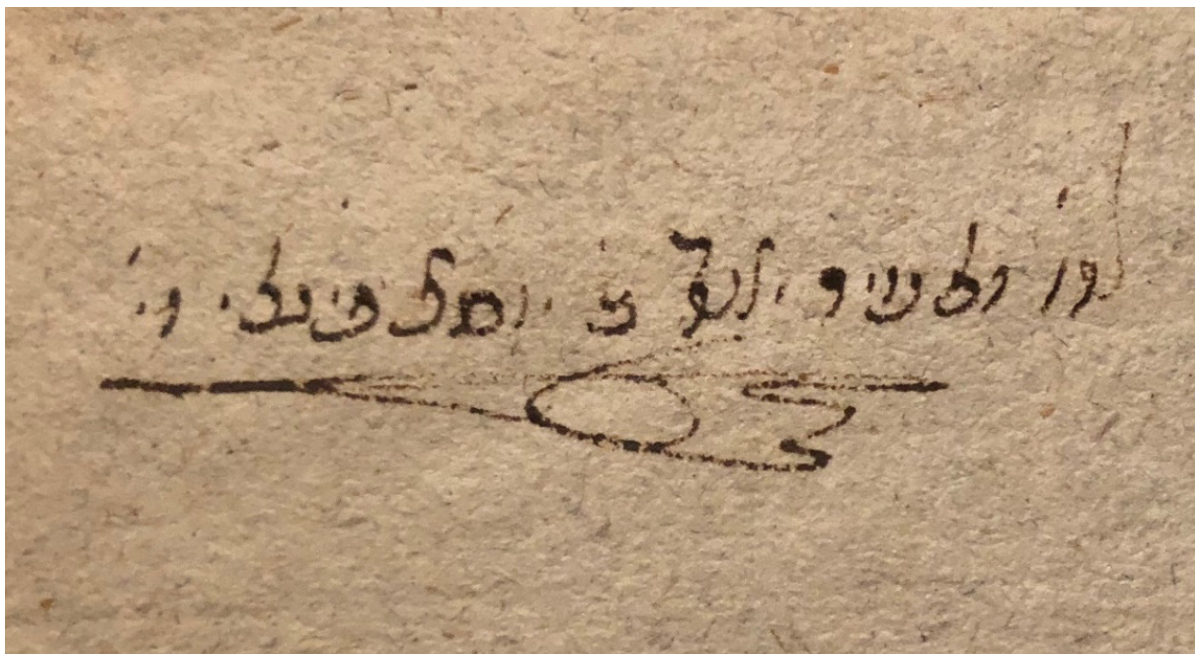

Fig. 4. Ham Ribbi Jeuda ben Josef Finci’s signature (from my own collection) 


\section{Reading Zohar as Mussar: Oral and Written Discourses on the Zohar in the Sephardic World}

Originating from such a rabbinical and kabbalistic "dynasty", Ham Ribi Avram was probably "the best person for the job". Rather than dealing with cosmogony or theosophy, his Leket a-Zoar deals with Mussar, usually translated as Jewish ethics.

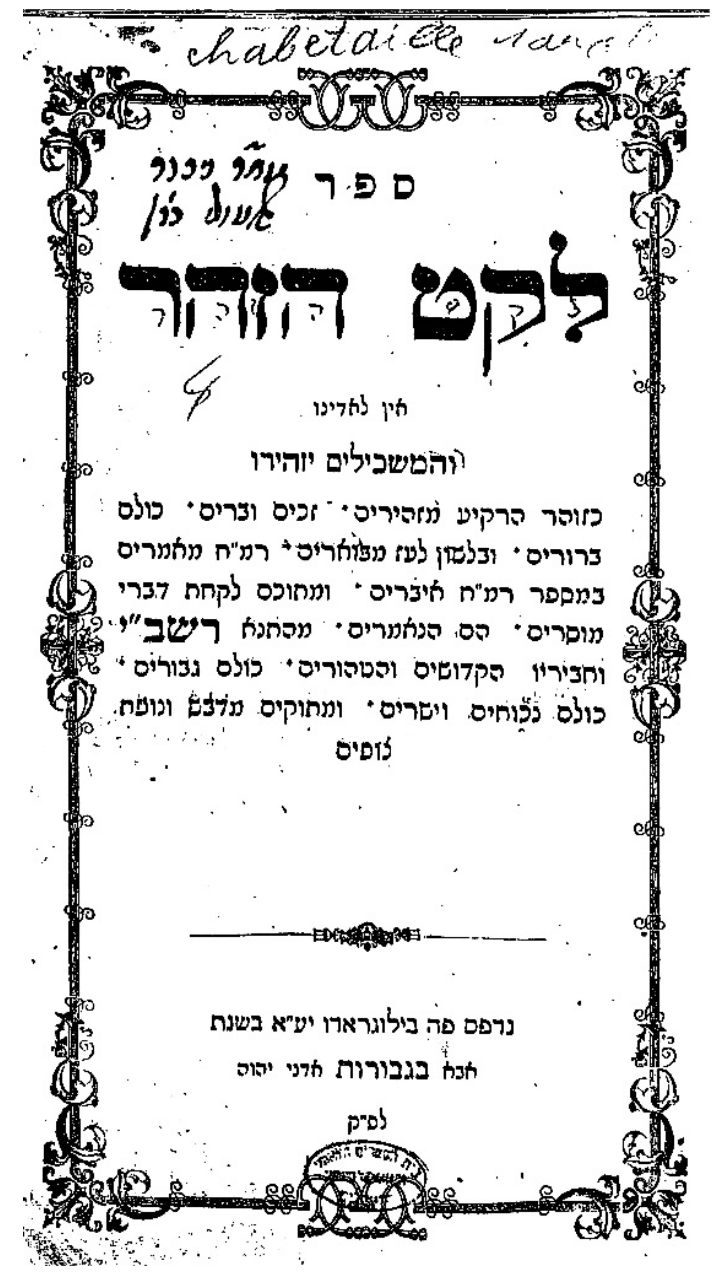

Fig. 5. The front page of the Belgrade edition of Leket a-Zoar 
According to its front page, the anthology should contain 248 excerpts from the Zohar, in order to resemble the 248 organs ascribed to the male body by the sages of the Talmud:

Two hundred and forty-eight excerpts, according to the number of the organs, to learn from them words of Mussar (moral), spoken by Ribbi Shim'on bar Yohai and his friends, the holy and pure ones, all of them mighty men, and all their words pleasant and straight, sweeter than honey and nectar.

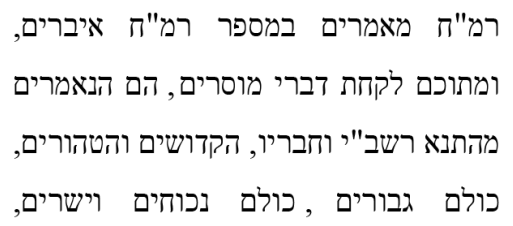

ומתוקים מדבש ונופת צופים.

However, not only the numeration of the excerpts throughout the first edition is lacking, but also their total number. ${ }^{20}$ In reality, in all three editions the anthology contains only 246 excerpts from the Zohar, 121 of which end with Finci's own reflections and a resumé of the moral of the story. Many of Finci's discourses are masterpieces of the traditional Judeo-Spanish oral genre of darush, used by the learned elite to convey values and Weltanschauung to the common masses. Both rabbis who wrote the traditional approbations for Finci's Leket a-Zoar took its Mussar nature for granted. Thus,

20 The numeration of the paragraphs in all three editions is inaccurate. In the first edition, for example, up to paragraph 81 it is impeccable. Paragraph 82 lacks a number, but the subsequent paragraph is numbered as 83 , indicating that paragraph 82 was not skipped in counting but only in numeration. Some numbers appear in the numeration twice, due to the fact that paragraph 89 is misnumbered as 80,122 as 123,125 as 135 and 132 as 133 . From paragraph 144 (misnumbered as 147) to paragraph 246 (misnumbered as 199) that ends the anthology, the numeration does not reflect the reality of the order any more. The second, Salonica edition introduces its own mistakes in the paragraph numeration. It is accurate up to paragraph 145, but then the next paragraph is numbered as 149 , thus creating a gap of three paragraphs between the numeration and the reality of the anthology. However, two subsequent paragraphs after paragraph 183 are numbered as 184 , reducing the gap between the numeration and the reality of the anthology to two paragraphs only. Hence, the numeration ends with paragraph 248 (the number intended by the author), while this edition actually only contains 246 paragraphs. In this edition there is also some additional local misnumbering, which is subsequently immediately corrected. Thus, paragraphs 156 and 157 are both numbered as 156, but the subsequent paragraph is correctly numbered as 158 . The same is true of paragraphs 223 and 224 , which are both numbered as 224 , but again the subsequent paragraph is correctly numbered as 225. It should be noted that the third, Izmir edition mirrors the second and not the first edition of the anthology. Consequently, its paragraphs are misnumbered in the same way as in the Salonica edition and not the way they are misnumbered in the Belgrade edition. 
Benaroya (already mentioned above) calls it a collection of Mussar (morals) gathered from the Zohar:

The Co[mplete] Sa[ge], our
Ho[nourable] Tea[cher] and Ra[bbi],
Ri[bbi] Avram Finci, [May The]
Me[rciful] p[rotect] and [redeem him],
the brother of the Head, the Righteous
one, [Our] Tea[cher] and [our] Ma[ster]
and Ra[bbi], Ri[bbi] Josef Finci, [may
his] me[mory] li[ve in the] w[orld
to] c[ome], the Su[preme Rabbinic
Authority in the] Ci[ty]of Belgrade,
[may] G[od] p[rotect] i[t], and he
showed me the Mussar [= morals]
that he gathered and collected from
the Book of Zohar, for the commoners
who speak vernacular:

כי כן בא לפני הח[כם] הש[לם ] כבוד] מ[ורנו] ור[בנו] ה[רב] רבי אברהם פינצי נ[טריה] ר[חמנאי] ו[פרקיה] , אחיו של ראש, אותו צדיק מוהרי"ף זלה"ה מ[רא] ד[אתרא] בילוגראדו, י[שמור] ע[ליה] א[להים], כה הראני מוסר שאסף וקבץ מספר הזהר ללועזות בלעז...

At the same time, the rabbi of the Sephardic community of Vienna, Ham Ribi Reuven Baruh (also "a pure Sephardi”), the same one whom Ham Ribi Avram's brother, Josef Finci, replaced in the position of chief rabbi of Belgrade, states in his approbation that these "excerpts from the Zohar" are "speaking of requirements of the Mussar (= moral)":

Excerpts from the Zohar - collected sparks, enlightening dew from the Holy Book of Zohar, speaking of requirements of the Mussar, vital castigations, anthologised by our beloved Complete Sage, our $\mathrm{Ho}$ [nourable] $\mathrm{Tea}[\mathrm{cher}]$ and $\mathrm{Ra}[\mathrm{bbi}]$, Ri[bbi] Avram Finci, [May The] $\mathrm{Me}[\mathrm{rciful}] \mathrm{p}$ [rotect] and [redeem him].
לקט הזהר - נצוצים נקבצים טללי אורות מספר זהר הקדוש, המדברים בארש2 המוסר, תוכחת חיים , עלו בקבץ ע[ל ] [די ] אהובנו החכם השלם כ[בוד ] מ[ורנו ] י[רבנו ] ה[רב] ר[בי] אברהם פינצי נרי"ו, ויעתק משם אברהם אל ארש אחרת ${ }^{22}$ המהלך אתנו בעת כבודינו הורד בארץ ספרד, למען ירוץ הקורא.

\footnotetext{
21 Based on Psalms 21:3, (in the King James version 21:2, Thou hast given him his heart's desire, and hast not withholden the request of his lips. Selah).

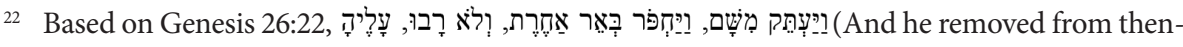
ce, and dug another well; and for that they strove not...).
} 
The following passage from paragraph 241 (misnumbered in the book as 243 ) is a good example of Finci's method of reading the Zohar as if it were Mussar literature: ${ }^{23}$

Ribi Shimon se iva para Tevarya, ${ }^{24}$ enkontro kon Eliyau a-Navi.

Le disho: "Shalom al senyor."

Disho a el Ri[bi] Shi[mon]: "En ke esta entremetido el She [m] Yitba[rah] en el sielo"? Le disho: "En korbanot, i disho palavras muevas de tu nombrado. Beata ti! I vini por akonantar a ti shalom. I demando de ti una koza, por ser maskim. En la yeshiva del sielo demandaron ke en ola $[m] a b[a]$ non ay en el komer ni bever, i ya dize el pasuk: 'Vini a mi guerta, mi ermana, novia, komi mi shara kon mi miel, bevi mi vino kon mi leche' [Kant. 5:1].

Disho Ri[bi] Shi[mon]: "I ke respondio el She [m] Yitba[rah]"?

Le disho: "El She [m] Yitba[rah] disho: 'Ya esta Bar-Yohay', i vini por demandarte."

Disho Ri[bi] Shi[mon]: "Kuanta kerensia akerensio el She [m] Yitba[rah] a Keneset Yisrael! I de muncha kerensia
R. Shimon was travelling to Tiberias. He met Elijah.

$\mathrm{He}$ (= Elijah) told him: "Greetings to the master". ${ }^{25}$

R. Shimon told him: "What is G[od,] $\mathrm{Ble}$ [ssed be $\mathrm{He}$,] engaged with in Heaven"? He told him: "He is engaged in sacrifices, and $\mathrm{He}$ [just] said new words in your name. Blessed are you! And I came to greet you. And there is one thing that I'd like to ask you to agree to. In the Heavenly Academy a question has been posed: In the Wor[ld] that is Com[ing] there is no eating or drinking, and yet the verse says: "I have come into my garden, my sister, bride: I have eaten my honeycomb with my honey, I have drunk my wine and my milk" [Song of Songs 5:1].

R. Shimon said: "And how did G[od,] Ble[ssed be $\mathrm{He}$,] respond"?

He told him: "G[od,] Ble[ssed be He,] said: 'Bar Yohay is already there', so I came to ask you".

R. Shimon [then] said: "How deeply G[od,] Ble[ssed be $\mathrm{He}$,] loves the Assembly of Israel! Out of great love, He changes how He normally acts.

23 .וזהר כרך ג (במדבר) פרשת פנחס [המתחיל בדף ריג עמוד א. For a direct English translation of the Aramaic original, see The Zohar: Pritzker Edition (translation and commentary by Daniel Matt), Stanford University Press, vol. IX, ad loci.

24 The traditional Sephardic pronunciation of the Hebrew name of Tiberias.

25 In Matt's translation it is R. Shimon who greets Elijah first, and immediately asks him a question about God's present occupation. In Finci's translation, however, first the prophet greets the rabbi, and then the rabbi asks him the aforementioned question. The Aramaic original, of course, in its paucity, allows for both these renderings. Nevertheless, from Elijah's servile attitude towards R. Shimon in the rest of the story, Finci's reading strikes me as the more convincing. 
troka sus echas de loke aze. Aun ke non su uzansa de komer i bever, por la kerensia suya, siendo i viene serka de eya, kome i beve. La novia entra a la hupa i kere komer. Non kale ke koma i su novio kon eya, aun ke non su uzo ansi? Esto es ke dize: 'Bati legani, ahoti, kala' - vengo onde eya, por entrar en la hupa."

"I enbezamos de David a-Meleh, ke konvido al She[m] Yitba[rah], i demudo sus echas de uzansa del She [m] Yitb[rah], i el She[m] Yitba[rah] izo su veluntad. Konvido a el Rey i a la Se[nyora], ke dize: 'Kuma Adonay limnuhateha, Ata vaaron uzeha' [Salmos 132:8], por non apartarlos. Troko los kelim i los maasim del rey, ke dize 'Koaneha yilbeshu ședek, vahasideha yeranenu'. Kalia ke diga 'Levieha yilbeshu ședek, velevieha yeranenu' [Salmos 132:9, 10], porke el ședek i rina era de los Leviyim, i non komo dize sedek a los koanim i rina a los hasidim. Disho a el She[m] Yitba[rah]: 'David, no es mi uzansa ansi'. Disho David: 'Baavur David avdeha [Salmos 132:10], koza ke yo Te apronti, non demudes de eyo'. Disho a el: 'Siendo me konvidates, kale ke aga tu veluntad'. I de aki enbezamos dereh ereș: ken konvida a otro kale ke aga su veluntad, aun ke non uza ansi."
Even though it is not his custom to eat and drink, because of His love, since $\mathrm{He}$ comes to her, $\mathrm{He}$ does eat and drink. When a bride enters the nuptial chamber, she wishes to eat. Shouldn't the groom eat with her, even though it is not his custom? That's [what the verse is] saying: 'I have come into my garden, my sister, bride' - I have come to her, to enter the nuptial chamber with her".

"We learn from King David, who invited God, Blessed be $\mathrm{He}$, and changed the actions to which God, Blessed be He, was accustomed, and God, Blessed be $\mathrm{He}$, did as he (= David) wished. He invited the King and the Lady, as it says: 'Arise, o Adonai, to your resting place, You and the Ark of Your Might'! [Psalms, 132:8] - The King and the Lady, so as not to separate them. He changed the vestments and the practices of the King, as it says: 'May your priests do righteousness, and may your pious sing of joy' [Psalms, 132:9, 10]. It [the verse] should have said: 'May your Levites do righteousness, and may the Levites sing of joy', because righteousness and the singing of joy belong to the Levites, and not the way it says, righteousness to the priests and singing of joy to the pious. G[od,] Ble[ssed be He], said: 'David, my custom is not that way'. David replied: 'For the sake of David Your servant [Psalms, 132:10], the thing that I've prepared for You, do not differ from it'. He told him: 'Since you have invited me, I should do as you wish'. 
"Topamos en Yaakov, kuando se fue onde Lavan, dize: 'I tomo de piedras del lugar' [Bereshit, 28: 11]., siendo ke vino el hatan onde la novia, aun ke su uzansa es a durmir en buenas kamas, i eya le aparejo piedras para ke se eche, todo ke resiva kon gusto. Esto es ke dize: 'Vayishkav ba-makom a-u' [ayi, en kontinuasion] - sovre akeyas piedras, aun ke su uzansa non es ansi. Tanbien aki: 'Ahalti yaari im divshi', aun ke non uza ansi, ma por la kerensia de la novia. I esto en kaza de la novia. En su lugar, ni kome ni beve, en lugar de eya - kome, i esto es: 'Bati legani vego[mer]'. Los malahim vinieron onde Avraam i komieron, aun ke eyos non komen, ni beven."

Disho a el: "Ribi, por tu vida ke el She [m] Yitba[rah] kijo dizir esta koza, i por non agradeserse kon Ke[neset] Yi[srael] disho ke digas tu. Beata ti, ke tu Kriador se alava kon ti ariva. Sovre ti dize el pasuk: șadik moshel be-yirat Eloim' [Shemuel II, 23:3].”
And from here we learn common courtesy, a person that invites a guest, the guest needs to do things the host's way, even if he is not accustomed." "[Thus] We find in Jacob, when he went to Lavan, [the verse] says: 'And he took of the stones of the place' [Genesis, 28:11]. Since the groom came to the bride, even though his custom is to sleep in good beds, and she prepared stones to lie on - he should accept it with pleasure. This is what [the verse] says: 'And he lay down in that place' [ibid.] - on those stones, even though it is not his usual custom. And here also 'I have eaten my honeycomb with my honey', even if $\mathrm{He}$ is not accustomed, for the sake of the love for the bride. And this is so in the house of the bride [not in other places]. In His own place He neither eats nor drinks, in her place - He eats, and that is [the meaning of the verse] 'I have come into my garden, my sister, bride'. The angels came to Abraham, and they ate - even though they neither eat nor drink.

He [= Elijah] told him [= R. Shimon]: "Rabbi, by your life, G[od,] Ble[ssed be $\mathrm{He}$, wanted to say this thing - and in order not to take credit for Himself, in the presence of the Assembly of Israel, He consigned it to you. Blessed are you, for your Creator above prides Himself on you. [It is] Of you [that] the verse says: 'The righteous one rules the awe of God' [II Sam. 23:3]”. 
This paragraph is representative of Finci's anthology as a whole on many levels. First of all, it shows what kind of Zoharic materials Finci chose to translate (the story itself contains practical moral guidance). No less importantly, it also illustrates Finci's approach to the translation and explanation of the text. For example, since he is not oriented towards theoretical Kabbalah, he does not dwell on complicated kabbalistic concepts such as Matronita. He simply translates this term into JudeoSpanish as Senyora (lady), without devoting even a single sentence to the term in his accompanying commentary. It is interesting to note that in the above-mentioned English translation of the Zohar, Daniel Matt feels a need to explain to his English readers that the words "invited the King and the Lady" actually mean that "King David invited King Tiferet and His Queen (or Matronita), Shekhinah, who is symbolised by the Ark" (referring in a note to Zohar I:148a-b, Moshe de Leon, Sefer ha-Rimon, 232-233 and Zohar I 36a). By contrast, Finci explains nothing here. His aim is not to educate his readership about theoretical kabbalistic concepts. Rather, he prefers to elaborate on the practical moral instruction already exposed in the story itself, by bringing in illustrative and convincing examples taken from the real life of the Ottoman (Bosnian) Sephardim:

De aki ke preve kuanto kale ser liviano en todo modo de perat kuando va en algun lugar musafir - o, afilu, seudat mișva, de non demandar i enfastiyar al baal a-bayit. Komo dizir, ay djente ke komen kon piron - i akel baal abayit non se le topa en su kaza tal koza, i non aparejo en la meza. Ke non sea ke se afishuge a demandar, ke se avirguensa akel baal abayit, i van a bushkar por los vizinos, siendo el non se sierve kon esto. Veken al ze adereh ay munchas kozas. Komo dizir, ay personas ke kaminan por sivdades, i le dan su baal abayit demanda loke non lo tiene ni visto ni oyido por sus kaza, i les dize: "Yo non esto ambezado a estas komidas, yo - mi komida es un poko de poyiko i un poko de pilafiko" - i akel baal abayit kale ke kite la kara de viruguensa. I kuando le
From here one should prove to oneself to what extent one is supposed to be easy-going in every single detail once one goes someplace as a guest - or even if one is only invited to a single obligatory festive meal that follows the completion of a religious duty. One should never impose on one's host or harass him. For example, there are people who eat with a fork - but their host doesn't have such a thing in his house and did not put one on the table. May it not be that one would annoy one's host by asking, since that would shame the host and make him go and ask his neighbours, since he doesn't use it. And there are many other things similar to this. For example, there are people who travel from city to city, and ask from their hosts things which they 
dan otro haham, non kere sintir de la nombradia, kuanto mal kavza akeya persona.

Ma esto mos viene de non meter tino en loke meldamos. Ken non save esto ke los malahim non komen, i onde Avraam komieron? Afilu las mujeres ya lo saven esto, i tanbien en boka de las kriaturas esta reglado: "En la sivdad ke estas, komo veras - ansi aras.” Ma todo viene ke mos keremos vender por muy delgado - i por esto pasa las palavras de los se[nyores] hahamim. El She [m] Yitba[rah] ke mos kongrasye de Su grasia para non salir del kamino verdadero! Amen! haven't seen or heard of throughout their entire lives. And he tells them: "I am not used to this food, my food is a bit of chicken and a bit of pilau rice - and then that host needs to hide his face because of the shame. And when they mention another learned person in front of him, he can't stand hearing about him, how much evil such a person causes.

But all of this happens only because we don't pay attention to what we are reading. Who doesn't know the fact that angels do not eat, but that at Abraham's table they did so. Even women know that, and even in the mouth of children there is a customary expression: "In the city where you are, what you see is what should be done". But it's all caused by the fact that we want to sell ourselves as very delicate - and because of that one finds oneself transgressing the words of the sages. May G[od,] Ble[ssed be $\mathrm{He}$ ], give us grace so that we do not leave the right path! Amen!

The original story from the Zohar starts with the question: if there is no eating and drinking in the world to come (and if Song of Songs is to be understood as a metaphor for the relationship between God and the people of Israel), how is it that the Divine groom himself is engaged in eating and drinking? The answer is that God is adjusting Himself to his host. The story proceeds to say that Jacob also adjusted himself to the customs of his host Laban, ending with the example of the angels who visited Abraham, eating from what he offered them (even though they usually do not eat or drink), in order not to cause him shame according to his own cultural codes. Talking actually of snobbism, Finci describes its causes with the following words: "Ma todo viene ke mos keremos vender por muy delgado" ("it all comes because we want to sell ourselves as if we were delicate"). 
Finci's example of putting the moral of the story into practice is fully immersed into his reading public's everyday life. In the latter half of the 19th century, Ottoman Jewry in general and Bosnian Jews in particular were exposed to an ongoing Western influence on all aspects of life. While some people were eager to accept Western customs and manners, others clung to their old Ottoman Sephardic ways. Typically for the Sephardic rabbinic elite, Finci is not opposed to innovations as such; rather, he is concerned with their ethical aspect. Western manners should not be used as a means of showing off one's own delicacy while putting others to shame and portraying them as backward and less cultivated. However, Finci does not chastise his public for its misconduct in an accusatory or finger-pointing manner. Rather, he uses the inclusive first person plural: We (all) want to sell ourselves for better than we actually are.

Finci's original and creative morals on stories from the Zohar certainly deserve their own separate study, but I hope that the examples given here suffice to illustrate the claim that Finci - whether as the selector of the texts included in his anthology or as their translator and commentator - is not interested in explaining theoretical kabbalistic terms and concepts (such as the Tree of Life, the sefirot or the parșufim). Rather, he reads the Zohar as if it were a work of Mussar, offering practical moral guidance. And by practical moral guidance I mean not only a list of actionable and desired social practices, but also the nurturing of a set of beliefs that lend transcendental meaning and metaphysical context to otherwise theologically irrelevant social niceties.

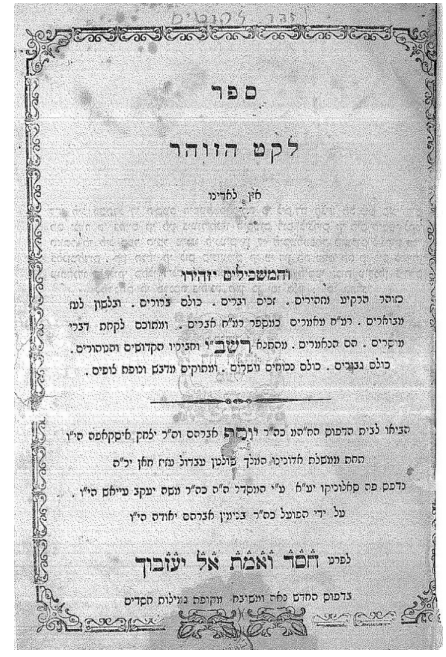

Fig. 6. The front page of the Salonica edition of Leket a-Zoar

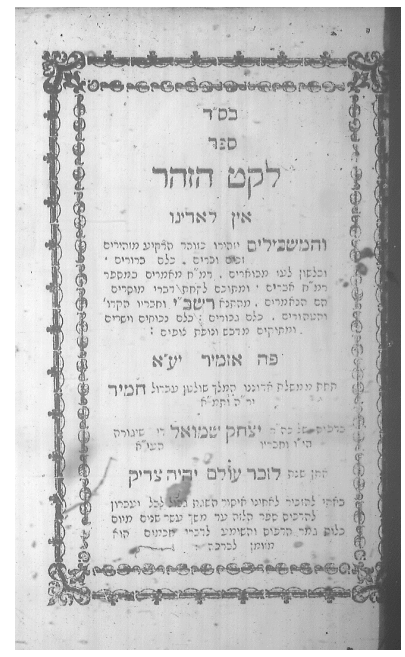

Fig. 7. The front page of the Izmir edition of Leket a-Zoar 


\section{Traditional Ways of Religious Learning in Bosnia: Sephardim versus Muslims}

While Finci's methodology of teaching the Zohar to common folk in the vernacular may be similar to the ways in which the same literary corpus was taught in other Jewish communities with their respective vernacular traditions (Judeo-Arabic or Yiddish), there are also striking similarities between Finci's way of teaching the Zohar to Bosnian Sephardic commoners and the methodology used by his Bosnian Muslim counterparts to convey traditional Sufi texts such as Jalāl ad-Dīn Muhammad Rūmī's Mesnevi to Bosnian Muslim common folk.

Sarajevo, the capital of Finci's Bosnia and Herzegovina, is renowned for its almost uninterrupted tradition of mesnevihans (public teachers of the Mesnevi) since the establishment of the Mevlevi tekke on Bentbaša in 1462. ${ }^{26}$ In a traditional Bosnian Muslim ders (oral discourse, compare Hebrew darush - "sermon") on the Mesnevi, the mesnevihan first reads a passage from the Persian original, then translates it into Bosnian, and lastly elaborates on it in a sermon that makes it relevant to his listeners' everyday moral conduct.

\footnotetext{
${ }^{26}$ It is hard today to restore a complete list of all the Sarajevo mesnevihans. Not all the sheikhs of the Mevlevi tekke on Bentbaša were necessarily mesnevihans, and not all Sarajevo mesnevihans were necessarily sheikhs or even dervishes of the Mevlevi order - but still, the two coincided most of the time. Here is a list of the sheikhs of the Mevlevi tekke in Sarajevo in the last 400 years: Atik-dede (end of the 16th and beginning of the 17th century), Tevekkuli-dede (first half of the 17th century, a known poet and mesnevihan), Sultan Ahmed (before 1662), Abdul Mahmut (before 1662), Sheikh Abdulfetah (died in 1709), Zuko Kablar (died in 1757), Sheikh Starac (died in 1757/58), Sheikh Ataullah (died in 1759/60), Sheikh Sarač Ahmed-eff. (died in 1770, at the age of 110), Mustafa Mlivar (died in 1777), Šeho Čelenger-Bravar (died in 1798/99), Sheikh Salih-dede/ Osman-dede (died in 1813/14), Sheikh Lutvullah (died in 1860), Muhamed Sheikh Fikrija Šehović (died in 1879), Sheikh Ruhija (son of Sheikh Fikrija, died in 1923/24). The last Mevlevi sheikh of Sarajevo was not a mesnevihan, and in his time Hadži Džemaludin-eff. Čaušević started giving ders on the Mesnevi, first (from 1911 to 1917) in the Mevlevi tekke and later (1917-1928) in the special dershana that Hadži Mujaga Merhemić (he used to sign his verses as Hajri - "the good one") established in his own home. Hadži Džemaludin-eff. served as mesnevihan for 17 years, but due to a bitter disagreement between him and the host of the ders, Merhemić, concerning the unveiling of Muslim women, the tradition was interrupted. It was reestablished by the same Hadži Mujaga in 1942. Just like his predecessor, Hadži Mujaga Merhemić served as mesnevihan for 17 years, until 1959. Following Hadži Mujaga’s death, the tradition was again interrupted for few years. In 1965 it was reestablished by Hadži Fejzulah-eff. Hadžibajrić, the sheikh of the Kadiri order and one of Hadži Mujaga’s students. Hadži Fejzulah-eff. served as mesnevihan for 23 years, until 1988. Still during his lifetime, he passed the ders into the hands of Hadži-Hafiz Halid-eff. Hadžimulić, who learned from both Hadži Mujaga and Hadži Fejzulah-eff. Just like his predecessor, Hadži-Hafiz Halid-eff. served as mesnevihan for 23 years, until 2011. Presently this noble tradition is kept alive by Hadži Hafiz-Mehmed Karahodžić, one of Hadži-Hafiz Halid-eff.'s students, who gives a weekly ders on the Mesnevi in the rebuilt Mevlevi tekke. For more information about each of the last mesnevihans, see Gadžo (2013).
} 


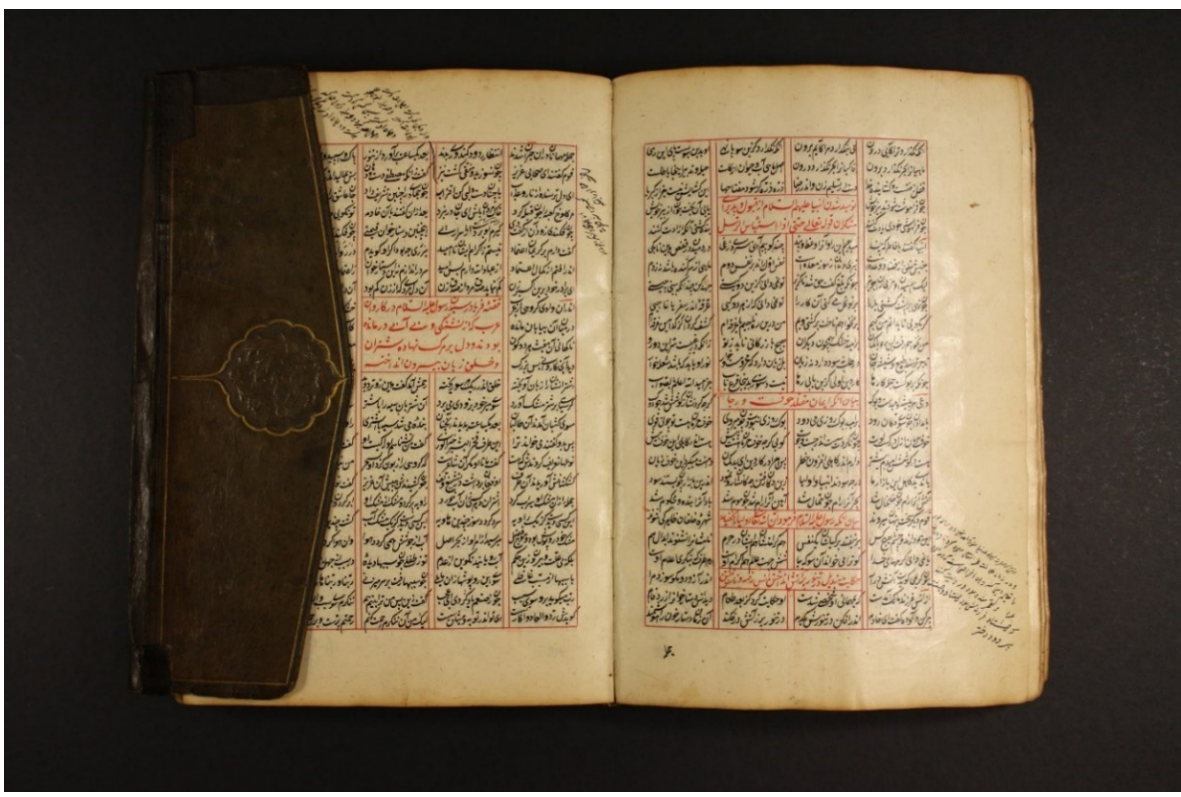

Fig. 8. Manuscript of the Mesnevi produced by the dervish Muhamed Bošnjak in 1647/48 for the Sarajevo tekke of the Mevlevi order, presently kept in Bošnjački Institut - Fondacija Adilbeg Zulfikarpašić

While academic lectures on the Mesnevi are more concerned with philological, philosophical and intertextual issues, traditional mesnevihans tend to concentrate on the moral messages, consequences and implications of the text.

On a few different occasions, I had the privilege of listening to a ders on the Mesnevi from the mouth of the famous Sheikh Fejzulah Hadžibajrić, better known in Sufi circles as Fejzi-Baba, the venerated sheikh of the Hadži Sinan's Tekke of the Kaderi order. ${ }^{27}$ Unlike the sheikh, who was well-versed in Persian language and literature, his listeners were simple Bosnian Muslims, usually with no knowledge of Persian language and literature. As a rule, they showed great appreciation for the sheikh, for the text he was rendering accessible to them, as well as for its revered author. However, discussing Rumi's language with them, his possible sources or his philosophical concepts would not only have been futile but also highly inappropriate. Even Hadžibajrićs edition of his Bosnian translation of the Mesnevi reflects this orientation towards an easily applicable religious message (Rumi, 2000, 2002), albeit to a much lesser extent than his oral

${ }^{27}$ For the sheikh's intellectual biography, see Beglerović (2014). 
ders. While the sheikh's reading public might be heterogeneous, belonging to different intellectual traditions, the audience of his oral discourses was composed exclusively of people from traditional circles, with a strong Sufi orientation, who came to the ders for moral guidance above all. They took the religious text seriously and were eager to let it improve them. The undeniable artistic beauty of the text was helpful, but it was a vehicle and not the goal. To their minds, the function of the text was to help them become better people or, more precisely, better practitioners of Islamic ethics.

Tragically, the Holocaust of the Bosnian Jews following the German attack on Yugoslavia and the Croatian occupation of Bosnia and Herzegovina totally obliterated all the traditional ways of learning of the Zohar in this country. However, while reading Finci's translations of excerpts from the Zohar, pictures from my personal experiences in the traditional Bosnian Muslim derses on the Mesnevi continually came to my mind. The methodology of Finci's sermons on the Zohar is the same as that applied by Hadžibajrić in his derses - an approach he described in the following terms in his introduction to the first volume of his translation of the Mesnevi:

These lectures were a tradition of Sarajevo, and their structure looked like this: reading of the original text, i.e. of the verses, according to the rules of metrics, their oral translation, elaboration of harder passages and Sufi concepts. (Rumi, 2000, p. 13)

However, Haddžibajrić's own printed edition of the Mesnevi skips through the Persian original without presenting it in its original Arabic alphabet or in Latin transliteration. Rather, only Haddžibajrićs own translation of the original text is presented, followed by his explanations, elaborations and remarks. The author testifies that the printed edition of the translation evolved from the oral discourses:

The first discourse was given in my home, on 15 September 1966. Abdulah Fočak taped my translation and the ders from the Mesnevi. Later, he would type them on a typewriter.... Oral translation is not the same as written. During oral translation, the translator is also led by his listeners and their level of education. The Mesnevi is one of the most important and voluminous works of Sufi thought and ethics. It is abundant with allegories, and this makes literal translation even harder. I paid special attention to the allegoric aspect, since this is the finesse of the tasawuf... The [series of oral discourses on the] first volume of the Mesnevi was completed on 21 April 1971. Abdulah Fočak typed all our derses, and it was then that I could dedicate myself to the separation of the text [of the translation] and the remarks.... During the oral discourses, it was much easier to give comments during the translation itself, so this later separation was a complicated issue. (Rumi, 2000, pp. 14-15) 
Similarly, Finci's own published discourses on the Zohar were probably originally delivered orally. During these oral discourses, the passages from the Zohar were apparently first read in their original Aramaic. Just as Hadžibajrićs Bosnian Muslim audience had a passive knowledge of Arabic as the language of their devotion and liturgy, while their command of Persian (the language of the Mesnevi) was basically non-existent, so Finci's Bosnian Sephardic public had a passive knowledge of Hebrew as their devotional and liturgical tongue, while their command of Aramaic was basically non-existent.

The reading of the text in the original mystical, revered but inaccessible language adds an aura of authenticity to the event and an aura of authority to the docent. Rather than being replaced by the translation, as in both printed editions, in the oral discourse the text in the original language is dominant. The process of learning and internalisation of the sacred text is not founded on the hypertext (the translation), but on the hypotext itself (the original Aramaic or Persian text). In the setting of a traditional oral discourse, the translation does not supplant the original text, but appears as a mere learning tool. The original text is a given, a constant waiting for the faithful to approach it with the assistance of a traditional intermediator. The translation, on the other hand, is not a given; it develops spontaneously on the spot, is mixed with reflection on the insights and morals of the hypotext, and has the modest aura of the ephemeral. ${ }^{28}$

${ }_{28}$ As an illustration of this tendency to keep the original sacred language in the oral discourse, but to skip it in the published transcription of the ders, compare the audio registration of one ders by Hadži Hafiz Mehmed Karahodžić (Feyzipaşa, 2017) to his own transcription of another such ders (Karahodžić, 2013). Sometimes, when publishing transcriptions of their derses, some mesnevihans do leave some of the original Persian verses in the discourse, probably in order to give it an aura of authenticity. However, this "sprinkling" of the discourse with some Persian verses is far from consistent as a methodology, as that would have to contain all the discussed verses in the original Persian script and/or their Latin transliteration, followed by a translation and elaboration. For an example of a transcription of a ders sprinkled with some Persian verses (only in the original Arabic script), see Hadžimulić (2013b). Until now I have only seen a published transcript of an oral Bosnian ders on the Mesnevi that contains Latin transcription of all the Persian verses elaborated in a discourse. Interestingly, these were notes taken by Hadži Hafiz Halid-eff. Hadžimulić (who would later become a mesnevihan himself) during one of the derses of his teacher and predecessor (as mesnevihan), Sheikh Hadžibajrić. It was published after Hadžimulićs death, by his students (Hadžimulić, 2013a). At the same time, a published transcript of a ders which elaborates on the Arabic introduction to the third volume of the Mesnevi does contain a Latin transcription of the Arabic text, probably because Arabic, as already stated, was much more accessible to the lay audience of the oral discourse as well as to the eventual readers of its published edition; see Hadžimulić (2013c). Interestingly, Hadžimulić also attended the derses of Hadžibajrićs teacher and predecessor, Hadži-Mujaga Merhemić, and took notes. Thus, Hadžimulićs transcript of one of Merhemićs ders was published by Hadžimulićss students (Merhemić, 2013). It seems that Hadžimulić’s Persian was still not good enough to provide the transcription of the Persian verses elaborated by Merhemić, as he would do much later when taking notes on Hadžibajrićs ders (see above). 
In both printed texts, Finci's edition of selected texts from the Zohar and Hadžibajrićs edition of the first two volumes (out of six) of the Mesnevi, the translation had to be disentangled from the insights, morals and elaborations. Interestingly, however, while Hadžibajrić himself testifies to the oral original of his translation and comments on it, in Finci's case, due to the lack of any disclosure of the methodology in the introduction, the originally oral character of the translation and the associated derushim must be deduced from the traces of orality preserved in the published text. The author's language is that of an oral discourse rather than of scientific speculation. Moreover, too many of Finci's excerpts are followed by a supplication related to the moral of the story (and a concluding "Amen"). This kind of interpolation would be quite unusual for the written Mussar literature or Me'am Lo'ez. However, in the context of an oral darush it is not only expected, but more of a requirement. As a rule, traditional Sephardic darush (just like a khutbah in a mosque or a ders in a tekke) concludes with the darshan's supplication for Divine help and guidance, for himself and his audience (hence the first person plural), so that they might be able to apply in practice the moral teachings of the canonical text that were touched upon in the darush. Even derushim which have a more theoretical or intellectual angle conclude with a supplication, but traditionally these supplications usually demand rapid redemption, the appearance of the Messiah or the restoration of the Temple service. While the latter supplications are usually short, being single-sentence formulas followed by a single "Amen" shouted loudly by the audience, the supplications asking for personal and collective guidance tend to be longer, and the audience interrupts the supplicant with loud "Amens" at the end of each unit.

Out of the 246 excerpts from the Zohar in Finci's anthology, 124 are followed by supplications related to the moral of the excerpt. While it is totally safe to say that supplications are much more typical of the paragraphs which contain a darush (which, one could argue, "invites" a supplication for Divine guidance in the application of the moral of the story) than of excerpts which include only the translation of the excerpt, the "supplication/no supplication" axis is not compatible with the "darush/no darush" axis. Out of the anthology's 246 paragraphs, 121 include derushim and 125 do not. Out of 121 paragraphs which contain a darush, 117 contain supplications. However, there are also four instances (paragraphs 120, 124, 125 and 129$)^{29}$ in which the darush concludes without a supplication. ${ }^{30}$

\footnotetext{
29 As mentioned earlier, the paragraphs in all three editions are misnumbered. The numeration used here does not follow the numeration of any of the editions, but rather the actual order of paragraphs, which is the same in all three anthologies.

30 There are also three occasions (paragraphs 97, 181 and 216) in which a single excerpt from the
} 
Out of 125 paragraphs which do not contain a darush, only seven paragraphs $\left(153,171,172,177,185,187\right.$ and 225) contain supplications. ${ }^{31}$ Out of the remaining 118 paragraphs which contain no supplications, 77 conclude with a technical Hebrew abbreviation that indicates the end of a quotation: ' $a$ [d] $k a[n]$ (u[ntil] he[re]), ${ }^{32}$ while 41 do not contain such an indication. Not surprisingly, the overwhelming majority of supplications (119 out of 124), regardless of whether they appear immediately after the excerpt (7) or only after the darush (117), conclude with "Amen". Most of them (97) conclude with a simple "Amen", ${ }^{33}$ but more elaborate formulas appear in some, such as: "Amen, ken yehi rașon" ("Amen, may it be God's will”, six supplications, paragraphs 6, 7, 8, 64, 174 and 200); "Ken yehi rașon, Amen" ("May it be God's will, Amen", 10 supplications, paragraphs 31, 82, 117, 153, 185, 187, 225 and 232) or "Bimehera veyamenu, Amen!" ("Fast, in our own days, Amen", four supplications, paragraphs 56, 136, 221 and 237). ${ }^{34}$

It should be noted that, unlike in various Christian denominational traditions, in which individual supplications may also end with an "Amen" uttered by the praying individual themself, in the various ethno-confessions that ascribe to Rabbinical Judaism, this traditional formula of declaration of affirmation usually represents the response of the congregation or participants in the liturgical or para-liturgical utterances recited by the cantor or prayer-leader (in the case of communal worship), the rabbi or darshan (in the case of supplications ending public discourses and sermons), the head of the family (in grace after meals, Kiddush and Havdalah, and other home-based para-liturgical services), or the ordinary fellow Jew (on hearing another utter a formal blessing over food or some other situation). The appearance of such a large number of supplications at the end of Finci's derushim (and/or his translations from the Zohar), all of them composed in the first person plural, strongly indicates that they were originally delivered in an oral setting such as public discourse. The fact that most of the prayers are accompanied by what in traditional Rabbinical Judaism constitutes a

Zohar is followed by two derushim, and each of them ends with a separate supplication. All six of these supplications are sealed with "Amen".

31 In four of these seven paragraphs (153, 185, 187 and 225) the supplication is followed by the expression "Ken yehi rașon, Amen", while in the three remaining paragraphs (171, 172 and 177) the supplication does not contain any traditional formula of declaration of affirmation.

32 As a rule, paragraphs which end with this technical mark do not contain any supplications.

33 Only on five occasions (paragraphs 60, 102, 115, 156 and 208), the translation of the excerpt from the Zohar is followed by a darush, sealed with a supplication which does not end with any traditional formula of declaration of affirmation.

34 There is a single occurrence of a darush (paragraph 13) which concludes with a supplication sealed with the words "Neșạ! Selah! Va'ed!", a formula of declaration of affirmation more typical of Judeo-Spanish magical incantations than of Sephardic liturgy, Hebrew or Judeo-Spanish. 
public response to the supplication or prayer, further strengthens the case for the original oral character of the material presented in Finci's anthology. As already stated, this feature is typical of public oral discourses.

Interestingly, although all of Hadžibajrićs oral discourses that I have attended in person ended with such a dovah (prayer), he chose not to include this in his printed edition of the Mesnevi. Finci, on the other hand, preferred to preserve the traditional supplications at the end of his derushim in their printed version.

For an illustration of Finci's supplications, I present three of them: the supplication that concludes paragraph 241 (misnumbered in the anthology as 243), discussed above, and the supplications which appear in paragraphs 199 (misnumbered in the anthology as 201) and 123, discussed below:

\begin{tabular}{|l|l|l|}
\hline 241 & $\begin{array}{l}\text { Ma todo viene ke mos keremos } \\
\text { vender por muy delgado - i por esto } \\
\text { pasa las palavras de los se[nyores] } \\
\text { hahamim. El She[m] Yitba[rah] ke } \\
\text { mos kongrasye de Su grasia para non } \\
\text { salir del kamino verdadero! Amen! }\end{array}$ & $\begin{array}{l}\text { But it's all caused by the fact that we } \\
\text { want to sell ourselves as very delicate } \\
\text { - and because of that one finds oneself } \\
\text { transgressing the words of the sages. } \\
\text { May G[od,] Ble[ssed be He], give us grace } \\
\text { so that we do not leave the right path! } \\
\text { Amen! }\end{array}$ \\
\hline $\begin{array}{l}\text { Se veyi ke grosh non yeva a a } \\
\text { Yerushalayim, otro ke zehut. } \\
\text { El She[m] Yitba[rah] ke mos mereska } \\
\text { a mereser i gozar en eya, kon mișvot i } \\
\text { maa[sim] t[ovim]. }\end{array}$ & $\begin{array}{l}\text { It shows that it's not money that brings } \\
\text { one to Jerusalem, but rather merit. } \\
\text { May G[od,] Ble[ssed be He,] give us the } \\
\text { privilege of deserving to enjoy it (=Land } \\
\text { of Israel), observing in it the Divine com- } \\
\text { mandments and doing good deeds. }\end{array}$ \\
\hline 123 & $\begin{array}{l}\text { I el Djidyo, ke se guadro a non } \\
\text { komer, eskapo a su alma. } \\
\text { El She[m] Yitba[rah] ke mos } \\
\text { mantenga en el Djudezmo! Amen! }\end{array}$ & $\begin{array}{l}\text { And the Jew, who kept himself from } \\
\text { eating [non-kasher food], saved his soul. } \\
\text { May G[od,] Ble[ssed be He], keep us in } \\
\text { Judaism! Amen! }\end{array}$ \\
\hline
\end{tabular}

It should be noted, however, that the supplications in Finci's published anthology do not necessarily totally faithfully reproduce the oral supplications which follow an oral darush with moral/practical focus in a traditional Sephardic community. As stated previously, this type of supplication usually consists of a series of petitions specified by the darshan/ supplicant, each of which is followed by a loud "Amen" from the public. The single-sentence supplications in Finci's anthology, followed by a single "Amen", are more like the one-phrase traditional formulas which follow more theoretically oriented derushim, or short derashot delivered by non- 
professionals during festive meals or on similar semi-liturgical occasions. It seems that in the process of preparation of the text for print, Finci chose to reduce these prayers to a single sentence only.

\section{Beyond Shared Methodology: Common Concepts and Beliefs}

The similarity between the Bosnian Sephardic and Bosnian Muslim traditions of learning religious texts is not limited to methodology. These texts often also disclose shared concepts and practices, or ideas and beliefs related to them. For example, Muslim, Sephardi and Orthodox Christian Bosnians all used to undertake demanding pilgrimages to their respective Holy Lands: Muslims to Mecca, naturally, and Jews and Orthodox Christians to the Land of Israel. For this pilgrimage, all three communities used the Arabic word hajj (itself a derivation of the Hebrew word hag "pilgrimage festival"). All three communities used to honour the people who completed the pilgrimage with the title hajji (in Ladino and in Serbian, often pronounced without the initial $h$ ) added to their personal names, or sometimes to their family names. Occasionally in Bosnian Jewish tradition, and often in Bosnian Muslim tradition, this journey would be a miraculous instant one, as "witnessed" by Finci in paragraph 199 (misnumbered in the anthology as 201):

De aki ke perkure el onbre kon toda su fuerza i poder a prekurar de suvir a morar en Ereș Yisrael i azer su morada ayi. Kuanto bueno su parte de akel ke es morador de akeas tieras, i komo mete mientes el onbre de morar ayi, el Dio ya le ayuda. Aun ke dizen la djente: "Yo, komo ago misvot i maa[sim] tovim], i en mi sivdad es Ereș Yisrael," esto non es sevara, porke i ayi puede azer mişvot i maa[sim] tovim], ke el lugar lo rekere. Basta tener zehut por ir ayi, ke se kere zehut grande. I non komo dizen la djente ke se kere groshes, todo es fantazia, ke el grosh non aze nada.
From here [it should be learned] that one should strive with all one's strength to make it possible for oneself to ascend to live in the Land of Israel and make it one's dwelling. How good is the destiny of the one who is an inhabitant of those lands, and as soon as a person sets his mind to go and dwell there, God helps him immediately. Even though people are saying: "Since I am observing the [Divine] commandments and doing goo[d] $\mathrm{d}$ [eeds], being in my city is just like being in the Land of Israel", that's not a [commendable] thought, because he can follow the [Divine] commandments and do goo[d] d[eeds] there also, since that place encourages it. It would be enough just to have the 
Yo me akodro kuando era kriatura, mala-mata el anyo de [5]573 (= 1813), Rosh hodesh Tamuz, se fue mi senyor papu, Ha[ham] Josef Finci a[lav] a[shalom] leir akodesh Yerushalayim, ti[bane] ve[timale] vi[meera] ve[yamenu]. Akel zeman avia un ani ke lo yamavan $\mathrm{Ha}[\mathrm{m}] \mathrm{Ri}[\mathrm{bi}]$ Shemuel. Era melamed, i vinia kada diya al kal kadosh por kantar las bakashot del Rav Nadjar zi[hrono] li[vraha]. I era onbre meduke beyisurin, i me parese ke era korto de vista. En mez de Elul aniz[kar], despues ke se fueron los adjis de Bosna, disho el ke se va a ir a la keșira al kazal. Se tomo la talega de tefilin, i se desparesio. Despues de Hanuka, ke vino arivada de los adjis ke partieron Tamuz, eskrive mi se[nyor] papu, a[lav] a [shalom]: "Vos dire, mi ijo, ke vinimos a kavos de Elul, i mos salio $\mathrm{Ha}[\mathrm{m}] \mathrm{Ri}[\mathrm{bi}]$ Shemuel aniz[kar] a karshe." Komo fue este Djidyo, i por onde se fue, non se supo. Se veyi ke grosh non yeva a Yerushalayim, otro ke zehut. El She[m] Yitba[rah] ke mos mereska a mereser i gozar en eya, kon mișvot i maa[sim] tovim]. merit of being able to go there, and great merit is needed for that. And it's not like the people say, that you need money, it's all fantasy, since money doesn't do a thing.

I remember when I was a child, more or less in the year [5]573 $(=1813)$, at the beginning of the month of Tamuz, my grandfather, $\mathrm{H}[\mathrm{am}]$ Josef Finci, pea[ce be upon] hi[m], to the Ho[ly] $\mathrm{Ci}[\mathrm{ty}]$ of Jerusalem, [may it be] bu[ilt] and fi[lled with people] fa[st] and [in our own days]. At that time there was a poor man by the name of $\mathrm{Ha}[\mathrm{m}] \mathrm{Ri}[\mathrm{bi}]$ Shemuel. He was a teacher in Jewish school, and he used to come every day to the Holy Synagogue in order to sing the religious poems of Rabbi Yisrael Nadjara, [may his] me[mory be a] bl[essing], [before regular prayers]. And he was smitten by all kind of Heaven-sent afflictions, and it seems to me that he was also short-sighted. In the mentioned month of Elul, after the hajjis from Bosnia had already left, he said he was going to a village for harvest. He took his phylacteries bag, and he left. After Hannukah, with the arrival of the hajjis who left in Tamuz, my Master and Grandfather, pea[ce be] $\mathrm{u}$ [pon him], writes: "Let me tell you, my son, that as we reached the end of Elul, the mentioned $\mathrm{Ha}[\mathrm{m}] \mathrm{Ri}[\mathrm{bi}]$ Shemuel just popped up in front of us". How that Jew got there, and via where, is not known yet. It shows that it's not money that brings one to Jerusalem, but rather merit. May G[od,] Ble[ssed be $\mathrm{He}$,] give us the privilege of deserving to enjoy it (=Land of Israel), observing in it the Divine commandments and doing good deeds. 
Finci's story, brought in the form of the testimony of his eminent grandfather, is meant to prove that it is not money that brings one to Eres Yisrael, but rather zekhut, one's metaphysical merits. Some people have money but never make it to the Holy Land and Holy City. At the same time, those who have zekhut, even if they live poor lives in the places where they are, can make it to the Land of Israel by way of Divine intervention. In those times, the hajj from Bosnia to the Land of Israel took approximately six months. It took the hajjis almost three months to get to the destination. They left Bosnia in the Hebrew month of Tamuz (which corresponds to the Gregorian June/July), arriving in Israel by the end of the Hebrew month of Elul (which corresponds to the Gregorian August/September). Obviously, they spent the holidays of the Hebrew month of Tishri (which corresponds to the Gregorian September/October) in the Holy Land, travelling back home for another three months, arriving in Bosnia already after Hanukkah, a Jewish holiday which ends in Tevet (December/January).

However, Ham Ribi Shemuel left Bosnia in Elul, arriving at the final destination of the Bosnian Jewish hajjis before they did. The author's grandfather had to travel back for almost three months, and it was then that he wrote his reminiscence. However, Ham Ribi Shemuel was probably taken back to Bosnia in the blink of an eye, the same way he arrived in the Land of Israel, by a Divine miracle.

This motif of a "magical journey" of an evlija (friend of God)35 or dobri (good person) to the Holy Land, Holy City and Holy Sanctuary is one of the central motifs of the folklore of Finci's Muslim compatriots. In Bosnian Muslim tradition, many a time the evlijas are hidden righteous people who do not belong to the religious establishment, but have attained a high position in the Divine eyes. This high metaphysical level is not attained through ordinary actions such as regular prayers, fasts and charity, but rather through some extraordinary achievement in the great jihad, as it is described in Sufi tradition, the permanent war with one's own ego. One of the most famous cases in Sarajevo oral tradition is the case of Merdžan-kaduna:

Muž joj je bio veliki pijanica, te ju je uvijek tukao. Ona je to stojički podnosila i šta više štap kojim ju je muž tukao omotavala je mekom krpom da on ne bi ruku nažuljio. Radi toga joj
Her husband was a great drunkard, so he always used to beat her. She endured it stoically, and she would even wrap the stick with which the husband beat her with soft cloth so that he wouldn't

The Bosnian term evlija developed from the plural ('awliyā أولياءُ) of the Arabic noun walī (, ولي ), usually used by Muslims to indicate an Islamic saint. For a detailed description and analysis of the phenomena, see Renard $(2008,2009)$. 
je Bog podario, da bude evlija. (Pričaju da žena može postati evlija za 40 dana, a muškarac ne može ni za 40 godina!!) (Smailbegović, 1991, p. 157) blister his palm. Because of that God gave her to be an evliya. (They say that a woman can become an evliya in 40 days, and a man not even in 40 years).

This oral tradition does not perceive Merdžan-kaduna as a masochist who enjoys her husband's violence. Her husband is not even central to the story. It is all between Merdžan-kaduna and God. She subjugates herself to her husband because she believes that it is God's will. Even if her husband breaks the law of Islam by drinking alcohol, she does not rebel against him by claiming that he is not entitled to use the prerogatives of a husband, as set down in the traditional patriarchal Sunni Hanafi Ottoman interpretation of Islam, against her. She submits to him, as a way of submitting to God's will. Her total submission is reflected in the fact that she wraps that part of the stick which is in his hand in a soft cloth, so that he does not hurt himself while hurting her, and not the part of the stick that hurts her. Her husband is not impressed. He is probably too drunk to even pay attention. However, there is someone who is impressed: the Almighty God himself. Once the dobri or dobra annuls his or her will in order to subjugate themself to God and his laws, God annuls the laws of nature for such a person, to show them his love and appreciation:

Merdžan-kaduna. Ona je ukopana na Ravnim bakijama. I za nju su pričali da je bila onako vrlo poštena žena, čestita žena. Stanovala je na Gorici i pričale biše hadžije da su je viđale, u isto vrijeme kad su je viđale ovdje $u$ Sarajevu, da su je viđali u Mekki.

Jedan hadžija je, sad se neću sjetit tačno kako mu je ime bilo, negdi je stanovao oko Bistrika, kako li. To sam slušo i od hadži Mujage, rahmetli, Merjemića.

Otišo na hadž, i kako je prije bilo onih razbojnika, ovi, išlo se na devama pa
Merdžan-kaduna. She is buried at Ravne Bakije. It is said about her that she was an upright woman, an honourable woman. She lived at Gorica, and the hajjis would say how they saw her at the same time that she was seen (by others) in Sarajevo, they'd see her in Mecca.

One such hajji, I can't remember now what his name was, he used to live someplace near Bistrik, something like that. I've heard this also from Hajji Mujaga Merjemić.

[So that guy] Went to hajj, and before there used to be those robbers, you 
biše razbojnici zastavljali one karavane i opljačkali. I opljačkan je bio i on. Osto bez novaca. Poslije, nit mu je ko stio pozajmit da se vrati, niti je imo, more bit da nisu imali. Samo, tražio je od koga da vrati se. Nije imo, osto iza njiha. I kad su ove hadžije krenule, nije se, prije se išlo po nekoliko mjeseci. Kako su hadžije išle, on je osto iza njiha i da je jedno jutro klanjo sabah u harem-Šerifu i vidio jednu ženu u bosanskoj odjeći, u feredži i u onome. I kad je ova žena, pristupio je njojzi i upito je. Govorila je bosanski, bosanskim jezikom, nije govorila arapski. Onda reko joj: "Pobogu, sestro, da mi pomogneš."

I kako ga je ona dovela u Sarajevo. Kad je došo u Sarajevo, počeli su vikat - pa nije on ni bio na hadžu, jer mu nije niko vjerovao da je mogao tako brzo doć. know, they'd go on camels, and the robbers would stop the caravans and rob them. He was also robbed. He was left without money. Later, nobody wanted to give him a loan, he had none, maybe the other [Bosnian hajjis] didn't have any either. He was only looking to get some money from someone, to return. He didn't find any, and he stayed on. When these hajjis left, and before they used to travel [back] for a few months. So the hajjis left, and he stayed on, and one day as he was saying the morning prayer in the Noble Sanctuary, he saw a woman in Bosnian clothes, in ferejje and everything. When that woman... he approached her, and he asked her. She spoke Bosnian, in the Bosnian language, she did not speak Arabic. So he told her: "Sister by God, would you help me"?

[And I also heard] How she brought him to Sarajevo. When he came to Sarajevo, they started saying "he didn't even go to hajj" because nobody believed him that he could have returned so fast.

Similarly to Merdžan-kaduna, the hero of a Bosnian Sephardi hagiographical anecdote brought by Finci, a teacher in a local Jewish school smitten by all kind of Heaven-sent afflictions and short-sighted, strikes me as quite a marginal personality. However, while the representative of the religious establishment, the learned and honoured Ham Ribi Josef Finci the elder, needs to travel six months to earn the title of a hajji, the marginal sadiq is brought there in the blink of an eye, by direct Divine intervention. The most interesting part of this is that it is not an anti-establishment story developed and recounted in the social margins, but rather a story written down twice by the rabbinical elite, the first time being by Ham Josef, in a private letter to his grandson Ham Avram, to be included by the latter in his commentaries on the Zoharic stories. 
One of the main principles of this "love affair" between God and his friends is that it is private and intimate, and it is supposed to stay so. Consequently, both sides try to keep it from the public eye, and God's friends usually urge the people whom they help, and who become aware of their keramets, not to share this information with others:

\begin{tabular}{|c|c|}
\hline $\begin{array}{l}\text { On nije htio ni raspravljat. Ali ga je } \\
\text { ona zamolila da ne kazuje taj slučaj } \\
\text { kako ga je ona dovela. I kad je ovaj, } \\
\text { on je poslije dolazio njoj kao sestri } \\
\text { svojoj i ona njemu, al' da je ona } \\
\text { vrlo s mužem živjela u lošem. I kad } \\
\text { je umrla, da je on nosio na groblje, } \\
\text { nije dao drugom svijetu da nosi, nego } \\
\text { reko: "Ja ću nju nosit. E, to je ona } \\
\text { žena koja je mene vratila." }\end{array}$ & $\begin{array}{l}\text { He didn't want to discuss it. She asked him } \\
\text { not to tell [anyone] that it was she who had } \\
\text { provided for him. And later, you know, he } \\
\text { used to visit her, like his own sister, and } \\
\text { she'd visit him, but she had a bad time with } \\
\text { her husband. When she died, [I heard that] } \\
\text { he took her to the cemetery, he wouldn't } \\
\text { let others carry her, rather he said: "I'll } \\
\text { carry her, she is the woman who brought } \\
\text { me back." }\end{array}$ \\
\hline
\end{tabular}

Similarly, the hero of Finci's Jewish story of a miraculous hajj tried to obscure his future miraculous journey by telling everyone that "he was going to a village for a harvest."

The motif of a miraculous journey, of course, is not unknown in pre-Islamic Jewish literature. Talmud Yerushalmi (Tractate Ma'aser Sheni, $\mathrm{V}: 2$ ), for example, tells the story of an Israeli shepherd who, following his ox, found himself miraculously transferred to Babylon. The text connects the phenomena to biblical verse in Lamentations 3:9, which reads: רָּ ("He hath enclosed my ways with hewn stone, he hath made my paths crooked"). Thus, the phenomenon can be seen as 'ivut ha-nativ (curving the path), and is not necessarily a positive one. Rather than being a miracle performed on behalf of a worthy person, it is a kind of Divine sabotage.

The Babylonian Talmud (Sanhedrin 95), however, mentions Qefisat haareș (jumping of the Earth, i.e. shortening of the way) as an obvious Divine alteration of the natural order of things, which took place only three times in the entire Bible: once with Avraham's servant Elie'ezer (while he was on the sacred mission of bringing a wife for his master's son), another time in the case of the patriarch Ya'aqov and, the third and last time, in the case of Avishay ben Seruya, when reaching out to his uncle, King David, to save him from the revenge of Ishbi-benob, Goliath's brother:

Now that day was Sabbath Eve, and Abishai the son of Zeruiah, washing his head in four gribahs of water, remarked some bloodstains [therein]. Others say a dove came 
and beat [its wings] before him. Thereupon he reasoned: Israel is likened to a dove, as it is written, ye are as the wings of a dove covered with silver [Ps. LXVIII, 14]; this must be an intimation that David is in trouble. So he went to his house, but did not find him. Now, said he, we learnt, one may not ride upon his [sc. a king's] horse, nor sit upon his seat, nor use his sceptre: but how is it in a time of danger? So he went and propounded the question in the schoolhouse, and was answered, "In time of danger, it is permitted". He then mounted his [sc. David's] mule and rode off, and the earth contracted under him....

Our Rabbis taught: For three did the earth shrink: Eliezer, Abraham's servant, our father Jacob, and Abishai the son of Zeruiah.

Abishai the son of Zeruiah, as has just been narrated.

Eliezer, Abraham's servant, as it is written, And I came this day unto the well [Gen. XXIV, 42], implying that he had set out on that day.

Our father Jacob, as it is written, And Jacob went out from Beer-sheba, and went to Haran [Gen. XXVIII, 10]; which is followed by and he lighted upon a certain place, and tarried there all night, because the sun was set [Ibid, 11]. For when he reached Haran, he said [to himself], "Shall I have passed through a place in which my fathers prayed, without doing so likewise!" He wished therefore to return, but no sooner had he thought of this than the earth contracted, and immediately he lighted upon the place. [the objective of his journey]

It seems that the Talmudic interpretation of the three biblical accounts is anthropocentric. The Earth jumps in a miraculous way on behalf of three extraordinary people: on behalf of Abraham (to make it possible for Eliezer to fulfil his master's will), on behalf of Jacob (absolving him of the need to return to a holy place and pray there before his long journey to Haran) and on behalf of David (to make it possible for his nephew, Abishai, to come in time to save him). The direction of the journey seems to be less crucial.

Bosnian Muslim saints are also known to undertake mystical journeys to places other than Mecca. However, the dominant motif is that of the mystical journey to the Noble Sanctuary. Finci's story reflects both these traditions, the older rabbinical one as well as the younger, local (Bosnian) Islamic tradition. Not only is Ham Ribi Shemuel's journey hajj-centric (the aim of the miraculous journey and its witnesses being exactly the same as in local Muslim traditions), but the very hero of the story resembles the marginal heroes of Bosnian Muslim hagiography more than the very central biblical heroes of rabbinic culture. 


\section{What Did the Bosnian Sephardic Rabbinical Elite Know of Exclusively Muslim Concepts and Practices?}

Before concepts, practices or beliefs become shared and common, there must exist a high level of information among the minority group regarding the majority culture (or knowledge among different minority cultures). Accordingly, the question of the level of information possessed by Bosnian Sephardim and their rabbinical leaders concerning the beliefs and practices of their Muslim neighbours becomes crucial.

Fortunately, the moral of paragraph 123 powerfully exposes the high degree to which Finci was familiar with Islamic practices:

Kontare un paso ke tengo oyido komo viene a eskapar de la muerte el non enkonar la boka. Savras ke en Anadol avia un lugar ke se azia una feriya. I akel kamino era muy perso en keunto de ladrones. Una vez se fueron de una sivdad para akeyas feriyas tantos goyim. Bihlal avia un Djidyo kon eyos. Le disheron los goyim al Djidyo: "Si keresh vinir kon mozotros, kale ke te trokes el vestido, ke non te konoskan ke sos Djidyo," ke el Djidyo siempre somos afamados. I akel Djidyo se troko el vestido, ke ninguno lo konosia por Djidyo. Al diya tresero se salieron de sus kazas. Vinieron en el lugar ke dishimos de ladrones. Avia ayi un han, se echaron ayi, i a la manyana, a las 10 del diya, disheron: "Mos echaremos aki, ke non ay otro lugar onde a pozar." Pasando una ora ke abasharon, se desho de vinir un djandar kon un koreo diziendo al handji ke aparejen un lugar, ke viene un dayan kon su djente, ke se va a ir para tal lugar, ke lo mando el rey.
I'll tell you [about] one happening how not defiling one's mouth can save one from death. You know how in Anatolia there was a place where they used to have a fair. And that road was very dangerous on account of robbers. One time many gentiles from a certain city went to that fair. Among them there was one Jew. The gentiles told the Jew: "If you want to come with us, you need to change your clothes, so that you would not be recognised as a Jew". Because we, the Jews, are always known. And that Jew changed his clothes so that no one could tell he was Jewish. On the third day they left their homes. They arrived at the place of the robbers that we have mentioned. There was an inn there, and they slept in it, and in the morning, at ten o'clock they said: "Let's stay to sleep here [additional nights], as there is no other place to stay". One hour after they came down [from their rooms to the main hall of the inn], a gendarme made an entrance with some post, telling the owner of the inn to prepare a place because a judge was coming with his people, on his way to such and 
I luego el handji aparejo una uda del han. Paso un poko, vino un dayan kon sus djandares. Komo la regla vieja, se asento a englena kon akea djente merkaderes ke avia en el han. I de vez en kuanto sospirava. Le demandaron los merkaderes: "De ke sospira el se[nyor]?" Les disho: "Savresh ke ay 2 diyas ke sali de la sivdad i deshi a la se[nyora] mal enkamada! Non se ke avria. Keria tener un haber."

Pasando un poko de ke estavan engleneando, vino un djandar otro i demando al handji: "Esta aki tal dayan"? Le respondio: "Si"! Entro en el han. Le demando: "Ke ay, ke no ay en la sivdad"? Le disho: "Todo bien"! Le demando: "Ke tal esta la se[nyora]"? Le disho: "El se[nyor] ke biva"!

Presto se alevanto el dayan i tomo abdes, i le kildeo el namas, komo sus uzansas. Denpues ke eskapo le disho al handji ke trayga miel i manteka, ke aga una halva por alma de la nifgeret. Ansi fue! Izo una halva, les trusho en la uda ke eran los viajantes, para ke koman djan-ichi.

Se arodearon todos, i el Djidyo kon eyos. Eyos komian de la halva, el Djidyo tomava el pan, azia ke metia la mano en el plato, a tomar halva, i komia solo el pan. Eskapando de komer, izieron la dova, komo sus uzansas, tomaron los chibukes, i el Djidyo se fue a su lugar, i eyos, a uno, a uno, se fueron such a place, where he had been sent by the king.

So the owner of the inn prepared a room at the inn. A little later, a judge came with his gendarmes. According to old custom, he sat down to converse with the merchants who were in the inn. From time to time, the judge would sigh. The merchants asked him: "Why is the ma[ster] sighing"? He told them: "You know, it's two days since I left the city, and I left my la[dy wife] sick in bed. I don't know what's going on. I wish I had some news [about her]". Some time after their conversation, a gendarme came in and asked the owner of the inn: "Is judge so and so here"? He answered him: "Yes"! He entered the inn. $\mathrm{He}$ (= the judge) asked him: "What's going on in the city"? He told him: "Everything is good"! $\mathrm{He}$ asked him: "How is my la[dy wife] doing"? He told him: "May the ma[ster] live"!

Immediately, the judge stood up, made ritual ablution before the prayer and made a funeral prayer for her, according to their customs. After he finished, he told the owner of the inn to bring some honey and butter and to make some halva for the soul of the deceased. So it was! He made some halva, and he brought it to the hall where the travellers were seated, so that they could eat it for her soul.

They all sat [on the ground] in a circle [around the table], and the Jew with them. They ate the halva, but the Jew would take bread, would make a gesture as if he was taking halva from the [common] plate, but he would eat bread only. When they finished eating, 
durmiendo. El Djidyo se sekleo de ver ke se van durmiendo, se salio a la puerta del han, de la vanda de afuera. Vido ke yamo el dayan a uno de sus djandares i le avlo. Vino akel a lado de akeyos i vido ke ya se durmieron. Le dio haber al dayan. Vino el kon la djente, i los enpesaron a deznudar. El Djidyo ke era afuera, vido ke esta aziendo, se fuyo para un lugar poko leshos del han, i vido ke los kitaron a todos afuera, i los izieron pedasos, i los echaron en un pozo ke avia ayi.

A la manyana fue el Djidyo a la sivdad i konto todo el paso a el pasha. I mando el pasha djente en molde de merkaderes, i les enkomendo ke non koman la halva. I por detras mando mas djente, por ver si ara ansi, ke lo apanyen bivo. I ansi fue, ke izo komo kontimos, i lo apanyaron bivo, i lo trusheron onde el mishne. Le pregunto por el echo, i le konto komo ay tantos anyos ke estava aziendo ansi, i les echava gueso de muerto majado dientro de la halva, i los adormesia a todos, i non sentian nada. I el Djidyo, ke se guadro a non komer, eskapo a su alma. El She[m] Yitba[rah] ke mos mantenga en el Djudezmo! Amen! they said a prayer according to their customs, took the pipes, and the Jew went to his place (= room) while they went to sleep one by one. The Jew was annoyed that they were going to sleep, and he took a walk outside the gate of the inn. He saw how the judge called one of his gendarmes and spoke to him. That one (= the gendarme) came near them and saw that they were asleep. $\mathrm{He}$ (= the judge) came with the people, and they started taking off their clothes. The Jew, who was outside, saw what he (= the "judge") was doing, and he ran away to a place some distance away from the inn, and he saw how they took all of them outside, and cut them into pieces, and dumped them into a well that was there.

The next morning, the Jew went to the city and reported the incident to the general. And the general sent people pretending to be merchants, and commanded them not to eat the halva. After them, he sent other people in order to see whether he (the "judge") would do the same again, in order that he might be caught alive. And so it was that he did [again] as we related, and he was caught alive, and they brought him to the King's representative. And he (= the general) asked him about the affair, and he (= the "judge") told him how many years he had been doing this, and how he was putting ground human bones into the halva, causing all of them to fall asleep and not feel anything. And the Jew, who kept himself from eating [non-kosher food], saved his soul. May G[od,] Ble[ssed be He], keep us in Judaism! Amen! 
Besides being something of a late Bosnian Ottoman version of the biblical story of Daniel (who was also saved by eating kasher), this story is important because it reflects the high level of information that Sephardic rabbis had concerning the practices of their Muslim compatriots. Thus, Finci knows that some Muslim jurists ${ }^{36}$ allow the Islamic funeral prayer to be performed even in the absence of the corpse. Bosnian Muslims call this ritual dženaza namaz. Just like any other namaz (an Ottoman Turkish word of Persian origin), this one also requires ritual ablution, called abdest. In Finci's JudeoSpanish rendition (I tomo abdes, i le kildeo el namas), abdest becomes abdes and namaz becomes namas. However, the "Judeo-Spanish" verb used by this Bosnian hakham is even more interesting: kildear, "to make". It is an obvious Judeo-Hispanisation of the Ottoman Turkish verb kılmak (to make). It is not used on a daily basis, as Ladino speakers normally prefer the simple Judeo-Spanish (f)azer, but it can be used in the context of describing Muslim practices, given that in such a context Muslims themselves would say namaz kılmak (to make a prayer). Finci's knowledge of Islamic law and its terminology strikes me as impressive. The subsequent description of Muslim folk practices upon the reception of the news of the death of a close family member, such as preparing and distributing halva for the soul of the deceased (djan ichi, in Finci's Judeo-Spanish rendition, can-için in Ottoman Turkish), is less impressive. I assume this must have been common knowledge among all Bosnian Sephardim, and not only the rabbinic elite.

\section{Conclusion}

As explained earlier, Finci's anthology is not an integral translation of the Zohar. It is not even a mere translation of excerpts from the Zohar. Rather, it is a translation of a very specific selection of texts. Finci selected the texts which in his mind could help an individual already devoted to the Jewish way of life to achieve moral perfection, to become a better Jew, ${ }^{37}$ better son, ${ }^{38}$ better father, ${ }^{39}$ better person, ${ }^{40}$ better neighbour ${ }^{41}$ and better citizen. ${ }^{42}$ It is

\footnotetext{
${ }^{36}$ For example, Abū 'Abdullāh Muhammad ibn Idrīs al-Shāfíī or Abū Muhammad 'Alī ibn Aḥmad ibn Sa'īd ibn Hazm.

37 By strengthening religious observance, both moral and ritual.

38 See, for example, Finci's derushim in paragraphs 23, 45, and 220 (misnumbered in the anthology as 218).

${ }^{39}$ See, for example, Finci's darush in paragraph 224 (misnumbered in the anthology as 226).

40 See, for example, Finci's darush in paragraph 241 (misnumbered in the anthology as 243), discussed above.

${ }^{41}$ See, for example, Finci's darush on sexual morality in paragraph 205 (misnumbered in the anthology as 207).

${ }^{42}$ See, for example, the above-quoted and analysed darush from paragraph 123. By virtue
} 
precisely this approach that transforms Finci's anthology into a traditional Mussar work. Most of the translated selections are followed by a traditional Sephardic rabbinical darush. ${ }^{43}$ These derushim underline the moral of the translated story by making it even more relevant and practical for Finci's audience. Reading the anthology, it is difficult to avoid the sense that it most probably developed from oral discourses. There are testimonies of the existence of Sephardic yeshivot for ba'ale batim. In these "non-professional academies", common people would gather once (or a few times) a week in order to engage in Jewish learning. In larger centres these gatherings were usually instituted by hakhamim or by talmide hakhamim. Learning a weekly Torah portion, Hoq le-Yisrael (a compendium of Jewish texts designed for daily or weekly study by commoners $)^{44}$ or $M e^{\prime} a m l^{\prime} e z$, was part of the regular curriculum of such a gathering. Such learning could be initiated or conducted by almost anyone. However, reading the Zohar in a non-ritualistic manner, with understanding and explanation, required professional guidance. Bearing in mind the fascination of ordinary Sephardim with the Zohar, weekly Zohar classes given by hakhamim to laymen must have been a "spiritual treat". Finci's Leket a-Zoar is probably the closest window we will ever get to such traditional Sephardic gatherings and to what was read, thought, asked and answered there. Unsurprisingly, in methodology and content the traditional learning of Bosnian Sephardim resembled the learning traditions of their Muslim neighbours, showing once again that settled communities such as the Ottoman Sephardim cannot be researched

of being a good Jew, the hero of the story was spared the violent death that was imposed on his Muslim friends by a criminal disguised as an Ottoman dayan (sic!, interestingly enough, Finci does not use the Ottoman Turkish equivalent of the Hebrew term dayan, namely: kadi - "judge"). However, the hero does not selfishly thank God for his own salvation and proceed with his life, having learned to avoid non-Jewish company in future. Rather, he acts like a concerned citizen. He reports the incident to the Ottoman pasha (general), who checks the Jew's claim and, after finding it trustworthy, arrests the criminals. Thus, not only the system is proven worthy of loyalty but also, thanks to a faithful Jew, a common threat is removed.

43 Since Finci's notes clearly have an originally oral character, applying the methodology that Aldina Quintana (2004, 2006b, 2006-2007) developed in her research on Mecam Locez to Finci's anthology could further our understanding of the dynamics of the creation of Judeo-Spanish rabbinic works.

44 Throughout the Sephardic world, Hoq le-Yisrael was used by businessmen and craftsmen who could not dedicate all their time to Torah learning. Immediately after morning prayer, while still wearing the taleth (prayer shawl) and tephillin (phylacteries), they would start their day by learning different types of sacred texts arranged around the weekly Torah reading. This method was developed by MoHaRaHU (Morenu we-Rabbenu ha-Rav Ribbi Ḥayyim Vital / our Master and Teacher Rabbi Hayyim Vital) in his Peri 'Es Hayyim (“The Fruit of the Tree of Knowledge”), following the example of his teacher ha-ARI (ha-Elohi Ribbi Yiṣhaq, divine Rabbi Yiṣhaq Luria). The digested texts were first issued in book form by Ham Ribi Yiṣhaq Barukh, but it was HYYA (Rabenu Hayyim Yossef Dawid Azulay) who brought the collection to its present form. 
only in the context of their affinity to the Jewish world. It is impossible to understand the way the Ottoman Sephardim developed Jewish concepts, practices and institutes without acknowledging the common Ottoman culture they shared with their Muslim and Christian neighbours.

\section{References}

Alexander, T., \& Papo, E. (2006-2007). Le-koha shel milla: le-hashe ripuy sfaradiyyimyehudiyim mi-pi nashim mi-Sarayevo [The power of the word: Sephardic magic spells from Sarajevo]. Jerusalem Studies in Jewish Folklore, 24-25, 47-303.

Beglerović, S. (2014). Tesavvuf Bosne u vidicima Fejzulaha Hadžibajrića: Vjerski i kulturni razvoj bosanskih muslimana u prvoj polovini XX stoljeća. Bookline.

Bunis, D. (1984). Munahe ma'akhalim u-minhage 'akhila be-Sefer Damśek 'Eli'ezer le-Ribbi 'Eli'ezer ben Shem-Ṭov Papo - ha-sifrut harabanit be-djudezmo kemekor le-inyane folklor ye-lashon [Elements of Hebrew and Balkan origin in the terminology of foodways in R. Eliezer Ben Sem Tov Papo's Sefer Dameseq Eliezer - Judezmo rabbinical literature as a linguistic and folkloristic resource] (Pt. 1). Jerusalem Studies in Jewish Folklore, 5-6, 95-151.

Bunis, D. (1993). A lexicon of the Hebrew and Aramaic elements in modern Judezmo. Magnes Press; Misgav Yerushalayim.

Bunis, D. (2001). On the incorporation of Slavisms in the grammatical system of Yugoslavian Judezmo. In W. Moskovich (Ed.), Jews and Slavs (Vol. 9, pp. 325-337). Hebrew University of Jerusalem.

Eventov, Y. (1971). Toledot Yehudei Yugoslavia [History of Yugoslav Jews] (Vol. 1.). (C. Rotem, Ed.). Hitahdut olej Yugoslavia in Israel.

Feyzipaşa, S. (2017, July 5). Hfz. Mehmed Karahodžić - 1. ders - Mesnevija - II. YouTube. https://www.youtube.com/watch?v=-jXP2dB1YCk\&t=352s

Finci, M. (1858-1859). Leket a-Zoar. [n. p.].

Gadžo, Š. (2013). Tradicija prevođenja, kazivanja i tumačenja Mesnevije u Sarajevu i nekim drugim mjestima u BiH. Behar, 116, 3-13.

Gaon, M. (1932). Maskiyot levav. Ha-Ma'arakh.

Hadžimulić, H. (2013a). Mesnevija: Treći svezak, drugi dio, drugi ders. Behar, 116, 37-39.

Hadžimulić, H. (2013b). Moj prvi ders iz Mesnevije. Behar, 116, 42-46.

Hadžimulić, H. (2013c). Pristup. Behar, 116, 29-35.

Kamhi, H. (1966). Sarajevski rabini. In S. Kamhi (Ed.), Spomenica: 400 godina od dolaska Jevreja u Bosnu i Hercegovinu (pp. 78-273). Odbor za proslavu 400-godišnjice dolaska Jevreja u Bosnu i Hercegovinu.

Karahodžić, M. (2013). Jedan ders iz Mesnevije. Behar, 116, 47-50.

Landau, L. (1980). Content and form in the Me'am Lo'ez of Rabbi Jacob Culi [Unpublished doctoral thesis]. The Hebrew University in Jerusalem.

Lebl, Ž. (1990). Jevrejske knjige štampane u Beogradu 1837-1905. Dečje novine.

Lebl, Ž. (2001). Do “konačnog rešenja”: Jevreji u Beogradu 1521-1942. Čigoja štampa. 
Lehmann, M. B. (2005). Ladino Rabbinic literature and Ottoman Sephardic culture. Indiana University Press.

Levi, M. (1969). Sefardi u Bosni. Savez Jevrejskih opština Jugoslavije.

Levy, M. (1996). Die Sephardim in Bosnien: Ein Beitrag zur Geschichte der Juden auf der Balkanhalbinsel. Wieser Verlag.

Maestro, J. (1991). Kehilat Sarayevo ben shete milhamot ha-'olam [The Sarajevo community between the two world wars]. In Z. Loker (Ed.), History of the Jews of Yugoslavia: Vol. 2. Jews of Croatia and Bosnia-Hercegovina in the modern era (pp. 249-300). Hitahdut Oley Yugoslavia.

Merhemić, H.-M. (2013). Priča o lovcu. Behar, 116, 22-26.

Molho, M. (1945). Le Meam-Loez: Encyclopédie populaire du sépharadisme levantin. Librairie Molho.

Nezirović, M. (1988). Algunos rasgos fonéticos del español anteclásico en el habla judeo-española de Bosnia. In M. Ariza Viguera, A. Salvador Plans, \& A. Viudas Camarasa (Eds.), Actas del I Congreso Internacional de Historia de la Lengua Española (pp. 1537-1545). Arco Libros.

Nezirović, M. (2002). Judenspanisch. In M. Okuka (Ed.), Wieser Enzyklopädie des europäischen Ostens: Vol. 10. Lexicon der Sprachen des europäischen Ostens (pp. 101-116). Wieser Verlag.

Papo, E. (2006). Pedigree, erudition and piety; involvement and mobility: The life story of Ribi Dawid ben Yacaqov Pardo - A case study in the making of traditional Sephardic Hakam. Miscelánea de Estudios Árabes y Hebraicos (sección de Hebreo), $55,171-189$.

Papo, E. (2006-2007). Les influences slaves sur le judéo-espagnol de Bosnie dans la littérature du 'Cercle séfarade. Yod: Revue des études modernes et contemporaines hébraïques et juives, 11-12, 315-337.

Papo, E. (2007). Serbo-Croatian influences on Bosnian spoken Judeo-Spanish as reflected in the literary works of the members of the Sephardic circle. European Journal for Jewish Studies, 1(2), 343-364. https://doi.org/10.1163/187247107783876329

Papo, E. (2008). Leshon etnit be idan ha-leumiyut: Ha-sefaradit ha-yehudit ha-bosnit ba-'et ha-hadasha [Ethnic language in an age of nationalism: Bosnian JudeoSpanish in modern times]. Pe amim, 113, 11-51.

Papo, E. (2013). German influences on Bosnian spoken Judeo-Spanish during the first half of the 20th century, the way these are reflected in the literature produced by the Sarajevo-based Sephardic circle. In M. Studemund-Halévy, C. Liebl, \& I. Vučina Simović (Eds.), Sefarad an der Donau, Lengua y literatura de los Sefardies en tierras del Habsburgo (pp. 295-312). Tirocinio.

Papo, I. (1981). Hebraizmi u govoru sarajevskih Sefarada / Hebraisms in the vernacular of the Sephardim in Sarajevo [Manuscript].

Papo, I. (1995). Turcizmi u jevrejsko-španjolskom Sefarada Bosne i Hercegovine. In M. Nezirović, B. Nilević, \& M. Rizvić (Eds.), Sefarad '92 (pp. 241-252). Institut za istoriju.

Pinto, A. (1987). Jevreji Sarajeva i BiH. Veselin Masleša. 
Quintana, A. (1997). Diatopische Variation des Judenspanischen in den Balkanländern und in der Türkei. Neue Romania, 19, 47-65.

Quintana, A. (2004). Sobre la transmisión y el formulismo en el Me'am Lo'ez de Yacob Julí. In H. Pomeroy \& M. Alpert (Eds.), Proceedings of the Twelfth British Conference on Judeo-Spanish Studies 24-26 June, 2001: Sephardic language, literature and history (pp. 69-80). Brill.

Quintana, A. (2006a). Geografía lingüística del judeoespañol: Estudio sincrónico y diacrónico. Peter Lang Verlag. https://doi.org/10.3726/978-3-0351-0275-8

Quintana, A. (2006b). Mivne ha-ś'iah be-sifre Me'am lo'ez le-Ribbi Ya'akov Kuli [The structure of the narrative in R. Jacob Culi's Me'am Lo'ez]. Pe'amim, 105-106, 79-151.

Quintana, A. (2006-2007). Formules d'introduction et structure discursive dans le Me'am lo'ez de Ya'aqov Khuli. Yod: Revue des études modernes et contemporaines hébraïques et juives, 11-12, 113-40.

Renard, J. (2008). Friends of God: Islamic images of piety, commitment, and servanthood. University of California Press. https://doi.org/10.1525/9780520940956

Renard, J. (Ed.). (2009). Tales of god friends: Islamic hagiography in translation. University of California Press.

Romano, S. (1995). Dictionnaire judéo-espagnol parlé - français-allemand, avec une introduction sur la phonétique et sur la formation des mots dans le judéo-espagnol. Misgav Yerushalayim.

Rumi. (2000). Mesnevija (Vol. 1). Ljiljan.

Rumi. (2002). Mesnevija (Vol. 2). Ljiljan.

Smailbegović, E. (1991). Priče o starom Sarajevu. Svjetlost.

Šmid, K. (2012). El Séfer Méšec betí, de Eliézer Papo: Ritos y costumbres sabáticas de los sefardíes de Bosnia. Consejo Superior de Investigaciones Científicas.

Ladino prevod odabranih tekstova iz Zohara Ham Ribi Avrama Fincija

kao rijetki uvid u metodologiju rada tradicionalnih

bosansko-sefardskih ješivot (obrazovnih klubova za odrasle),

te veza te metodologije sa lokalnom islamsko-sufijskom

tradicijom dersa

U tradicionalnoj sefardskoj kulturi, teoretska kabala je pretstavljala isključivo naslijeđe učene rabinske elite. Od sedamnaestog vijeka pa nadalje, mnogi pripadnici neobrazovanih sefardskih masa nalazili su i komplikovanije liturgijske tekstove (o spekulativnim da i ne govorim) teško razumljivim. Sljedstveno, rabinska elita je već tada počela sa obuhvatnim poduhvatom prevođenja osnovnih liturgijskih i pravnih tekstova na narodni jevrejsko-španski. Ipak, kao po pravilu, Zohar nije 
predstavljao dio tog kulturno-posredničkog preduzeća. Upravo zbog toga, do dana današnjeg nikada nije napravljen integralni prevod Zohara, ili barem jednog njegovog toma, na jevrejsko-španski. Različiti sefardski rabini prevodili su na narodni jezik samo vlastite izbore najpoučnijih tekstova iz ovog ogromnog korpusa. Ovaj rad analizira jedan takav zbornik odabranih odjeljaka, čuveni Leket a-Zoar, Ham Ribi Avrama (sina Mojsijevog) Fincija, objavljen 5619 (1858/9) u Beogradu. Fincijeva antologija sadrži prevod 246 odjeljaka iz Zohara, 121 od kojih završavaju Fincijevim vlastitim osvrtima i komentarima na tekst. Mnoga od Fincijevih narvoučenija predstavljaju remek djela tradicionalnog sefardskog usmenog žanra daruš (propovijed).

Kao komentator, Finci nije bio zainteresovan za razjašnjavanje zamršernih kabalističkih termina i koncepata. Radije, on čita i tumači Zohar kao da se radi o djelu iz musara (jevrejske etike). Izgleda da se u ovoj tačci sreću tradicionalni bosansko-sefardski način čitanja, učenja i tumačenja Zohara sa lokalnom bosansko-muslimanskom tradicijom čitanja, učenja i tumačenja klasičnih sufijskih tekstova, pokazujući još jedanputa kako jevrejske zajednice dugo ukorijenjene u određeni civilizacijski kontekst ne mogu biti proučavane samo u svjetlu njihovih posebnosti u odnosu na ostatak jevrejskog svijeta ili njihovih podudarnosti s istim. Nemoguće je razumjeti razvoj sefardskih koncepata, prakse i institucija bez uzimanja u obzir zajedničke osmanske civilizacije, u stvaranju i dinamičnom održavanju koje su Sefardi učestvovali skoro pola milenijuma, zajedno sa svojim muslimanskim i hrišćansko-pravoslavnim komšijama.

Ključne riječi: sefardske studije, sefardska kultura, literatura na ladinu, osmanski Jevreji, bosansko jevrejstvo, rabinska literatura na jevrejskošpanskom, sefardska homiletika, balkanska kultura, Jevreji Balkana.

Przekład Ḥam Ribi Avrama Finciego wybranych tekstów Zoharu na ladino jako rzadkie spojrzenie w metodologię pracy tradycyjnych bośniacko-sefardyjskich jeszybot (klubów edukacyjnych dla dorosłych) oraz jej związek z lokalną, islamsko-suficką tradycją homiletyczną

W tradycyjnej kulturze sefardyjskiej kabała teoretyczna była dziedzictwem wyłącznie uczonej elity rabinów. Od wieku XVII dla wiernych należących do niewykształconych mas bardziej skomplikowane teksty liturguczne (nie wspominając o spekulatywnych) były niezrozumiałe, dlatego też elita rabiniczna podjęła się zadania tłumaczenia podstawowych pism liturgicznych i halahicznych na język żydowsko-hiszpański. Ponieważ 
dzieła Zohar zwykle nie włączano do tego kulturalno-mediacyjnego projektu, do chwili obecnej nie powstał integralny, żydowsko-hiszpański przekład ani jednej z jego ksiąg. Różni rabini sefardyjscy przekładali na żydowsko-hiszpański jedynie własny wybór najbardziej pouczających tekstów pochodzących z tego ogromnego korpusu. Niniejszy artykuł analizuje jeden $\mathrm{z}$ takich zbiorów wybranych fragmentów, słynny Leket a-Zoar autorstwa Ham Ribi Avrama (syna Mojżesza) Finciego, wydany w Belgradzie w 5619 (1858/9) roku. Antologia Finciego zawiera przekład 246 fragmentów ksiąg Zoharu, z których 121 kończy się własnymi refleksjami i komentarzami Finciego. Wiele $\mathrm{z}$ tych wykładów Finciego to arcydzieła tradycyjnego sefardyjskiego gatunku ustnego darush ('kazanie').

Finci, jako komentator, nie był zainteresowany wyjaśnianiem zagmatwanych kabalistycznych terminów i konceptów. Chętniej czytał i tłumaczył Zohar jak dzieło musar - dzieło żydowskiej etyki. Jak się wydaje, w tym podejściu połączyły się tradycyjny bośniacko-sefardyjski sposób czytania, uczenia i tłumaczenia ksiąg Zoharu oraz lokalna bośniacko-muzułmańska tradycja czytania, uczenia i tłumaczenia klasycznych tekstów sufickich. Dowodzi to faktu, że wspólnoty żydowskie, zakorzenione w określonym kontekście cywilizacyjnym, nie mogą być studiowane jedynie przez pryzmat ich wyjątkowości wobec reszty świata żydowskiego ani przez pryzmat kongruencji z nim. Niemożliwe jest zrozumienie rozwoju sefardyjskich idei, praktyk i instytucji bez brania pod uwagę wspólnej osmańskiej cywilizacji, w tworzeniu i rozwoju której Sefardyjczycy przez prawie 500 lat brali udział razem ze swoimi muzułmańskimi i chrześcijańsko-prawosławnymi sąsiadami.

Słowa kluczowe: studia sefardyjskie, kultura sefardyjska, literatura ladino, Żydzi osmańscy, Żydzi bośniaccy, żydowsko-hiszpańska literatura rabiniczna, homiletyka sefardyjska, kultura bośniacka, Żydzi bałkańscy.

Przekład z języka serbskiego Aleksandra Twardowska

\section{Note}

Eliezer Papo, Hebrew Literature Department, Ben-Gurion University of the Negev, Beer Sheva

papoe@bgu.ac.il

The preparation of the article was self-funded by the author.

No competing interests have been declared.

\section{Publication History}

Received: 2020-05-21; Accepted: 2020-12-04; Published: 2020-12-31 